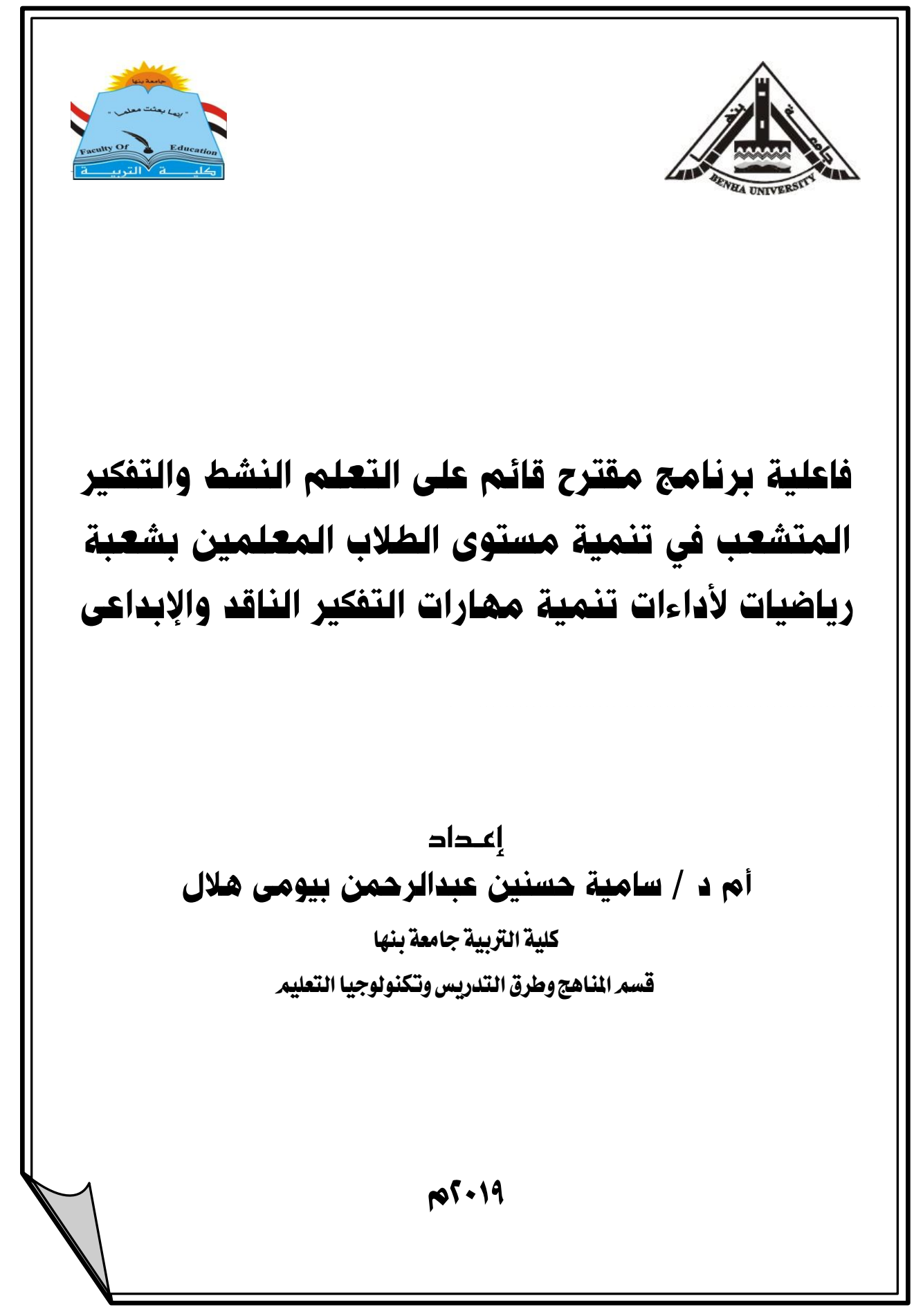




\section{فاعلية برنامج مقترح قائم على التعلم النشط والتفكير المتشعب في تنمية مستوى الطلاب المعلمين بشعبة رياضيات لأداءات تنمية مهارات} التفكير الناقد والإبداعى لئمين

إعـداد

أهم د/ سامية حسنين عبدالرحمن بيومى

كلية التربية جامعة بنها

قسم المناهج وطرق التدريس وتكنولوجيا التعليه

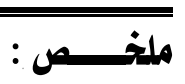

هدف البحث الى دراسة فاعلية برنامج مقتر ح قائم على التعلم النشط و التفكير المتشعب في تتمية مستوى الطلاب المعلمين بشعبة رياضيات لأداءات نتمية مهار ات التفكير الناقد و الإبداعي، وقد أعدت الباحثة البرنامج المقتر ح مكونأ من أربع وحدات (وحدة تمهيد ومر اجعة، وحدة تتمية مهار ات التفكير الناقد، وحدة نتمية مهارات التفكير الإبداعي، وحدة نموذج تدريسي مقترح لتتمية تلك الأداءات و التحصيل ) ، كما أعدت الباحثة إختبار المعرفيا لقياس الجوانب المعرفية في البرنامج و أداءات التدريس اللازمة لتتمية مهارات التفكير الناقد والإبداعي، وتم إعداد قائمة أداءات لنتمية مهار ات التفكير الناقد والإبداعي، بطاقة ملاحظة شملت ثلاثة أبعاد (أداءات تتمية مهارات التفكير الناقد، أداءات تتمية مهارات التفكير الإبداعي، أداءات بيئة التعلم اللازمة لتتمية مهارات التفكير عموما) ، ونم اختيار عدد (Tس) طالبأ وطالبة بالفرقة الر ابعة عام شعبة رياضيات بالفصل الدر اسى الثانى عام 9 ـ آم ، وتطبيق الأدو ات قبليا ، ثم تتفيذ البرنامج بشقيه النظري و التنريبي، ثم تطبيق الأدوات بعدياً ، وقد أثنارت النتائج الى فاعلية البرنامج المقتر ح لتتمية تلك الأداءات ، وأوضحت أيضا قوة تأثثر البرنامج في تتمية تلك الأداءات.

الكلمات المفتاحية ( أداعات تنمية مهارات التفكير الناقد والإبداعي ، التعلم النشط ، التفكير المتثعب ) 
The Effectiveness of a Suggested Program Based on Active Learning and Neural Branching Thinking in Developing Levl of Maths Students teacher's performances of developing Critical and Creative Thinking Skills

\begin{abstract}
The study aimed at investigating the effectiveness of a suggested program based on active learning and Neural Branching Thinking in developing Levl of Maths students teacher's performances of developing critical and creative thinking skills. The suggested program is prepared by the researcher and consisted of four units (introductory and review unit- Unit for developing critical thinking skills-Unit for developing creative thinking skills-Teaching unit model for developing the instruments and the achievement).The researcher prepared a cognitive test for measuring the cognitive aspects in the program and teaching performances for developing creative and critical thinking skills. She also prepared a list of performances for developing critical and creative thinking skills, an observation checklist included three dimensions ( performances of critical thinking skills developmentperformances of creative thinking skills development- Learning environment performances for developing thinking skills in general). The participants were 33 Maths fourth year students. In $2^{\text {nd }}$ Term 2019 The instruments were applied before and after implementing the program. The results revealed the effectiveness of the suggested program in developing these performances and showed its effect also.
\end{abstract}

Key Words : Performances of developing critical and creative thinking Skills, Active Learning, Neural Branching Thinking. 
مما لاثك فيه أن تقدم الأمم يقاس بإنتاجها للمعرفة وليس باستخدامها و استهلاكها ، من هنا يقع على القى

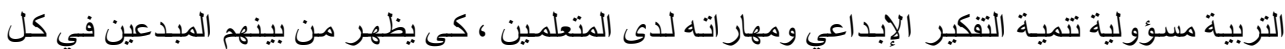

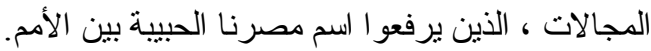

وحيث أننا في عصر يتسم بغز ارة المعرفة وسر عة وسهولة تداولها بين الأفر اد ، وذلك مـع تقدم

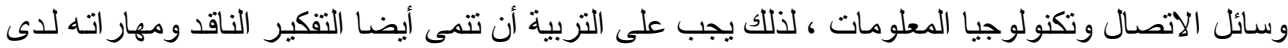

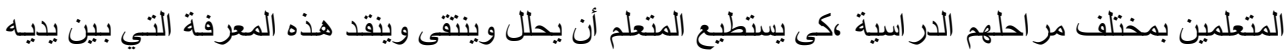

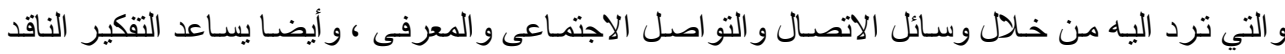

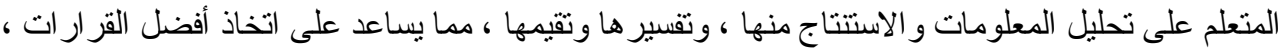

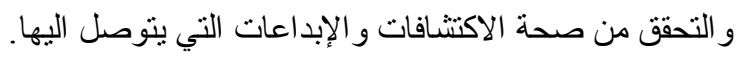

و إذا كان الإبداع هدفأ من الأهداف التي تسعي التربية إلي تحقيقها فإن المسؤولية الكبرى في تحقيقه

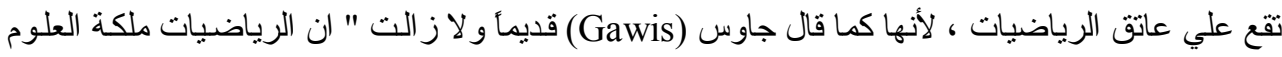

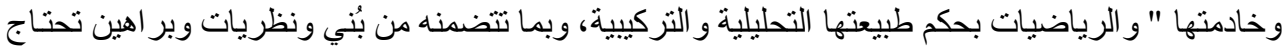

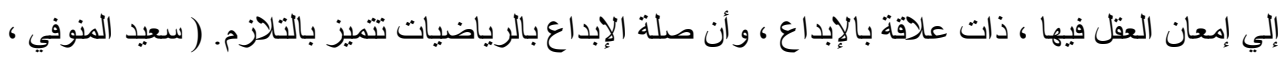

و الرياضيات من أهم المجالات المعرفية التي يعتاد فيها المتعلم التفكير العلمي الذي يستخدمه في

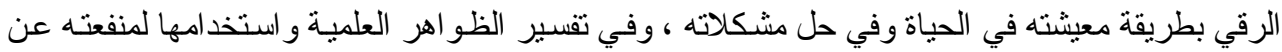
طريق التطبيق العملي لهذا التفكير الذي تعنبر الرياضيات أداة له.

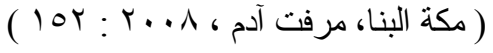

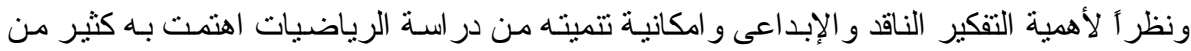

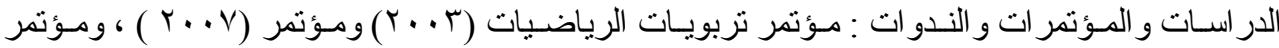

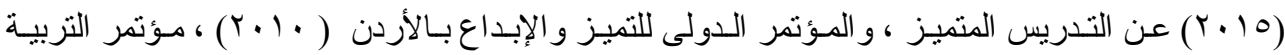

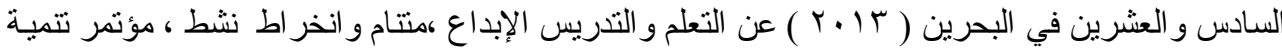

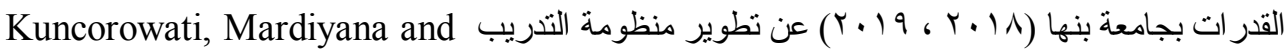
Karim Sevari Mar’atun Hasanah \& Edy Surya, 2017)) ،( R H DR S Saputro, 2017) and Maryam Falahi ( 2018) 
وتري الباحثة أن معلم الرياضيات بمهار اته و أداءاته التدريسية ، بسنطيع أن بنمى جميع مهار ات

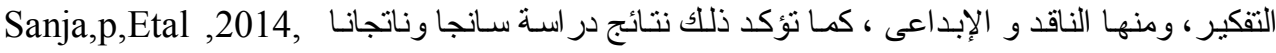
(4038 ) على وجود علاقة وثيقة بين مهار ات التدريس الإبداعى للمعلم وتطوير انجاز الطلاب وتحسين

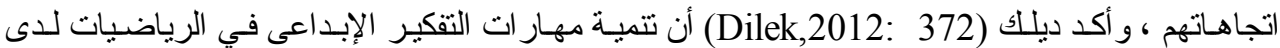
الطلاب تتطلب مهار ات تدريس إبداعية لدى معلمى الرياضيات تتعلق بتصميم التعليم و التعلم و الانشطة و إدارة النشاط وتتجيع الطلاب على التفكير بطرق منتوعة لانتاج حلول إبداعية.

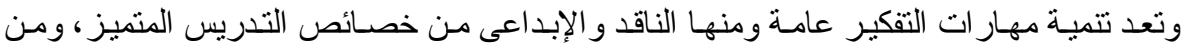

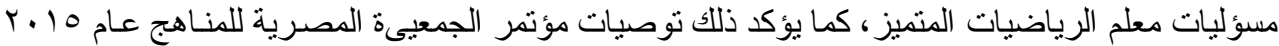

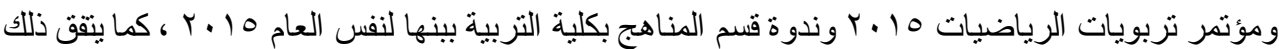

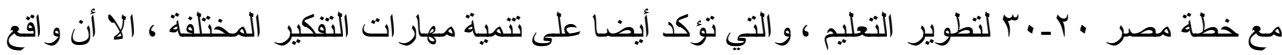

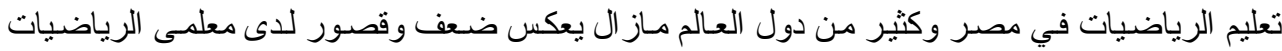
و الطلاب المعلمين في مهار ات وممارسات التدريس المنمية لمهار ات التفكير عامة و الناقد و الإبداعى خاصة

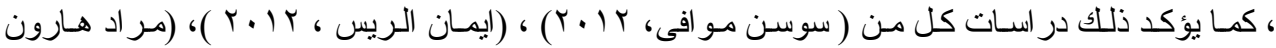

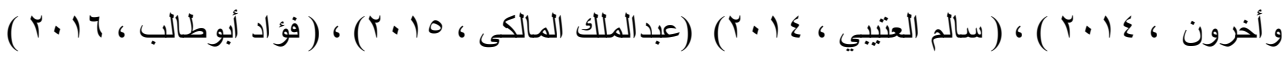

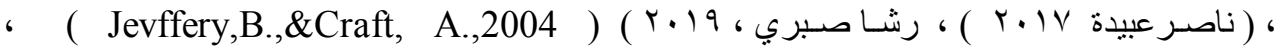
Jeffrey )، (Hossine, 2016) (Mollie,A.,2008) (Wood,R.,\& Asfield,J. 2008)

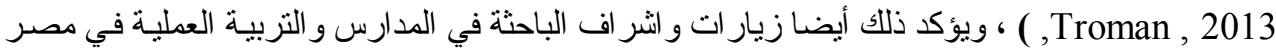

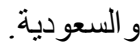

وحيـث أن استر اتيجيـات التعلم النشط تؤكد على نثـاط و إيجابية المتعلم ، و أثنتت عديد منها متل (الاكتثاف بأنو عه الموجه و الاستقر ائى وحل المشكلات و العصف الذهنى وخر ائط التفكير و الخر ائط الذهنية)

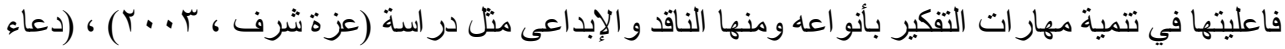

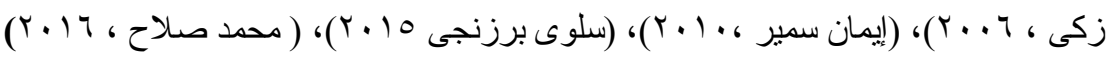
كما أن استر اتيجيات التفكير المتتعب متل استر اتيجية التفكير الافتراضي و التقكير العكسى تنتاسب مرونة التفكير ومن ثم التفكير الإبداعى ، وبعضها يتو افق مع مهار ات التفكير الناقد مثل استر اتيجية التتاظر

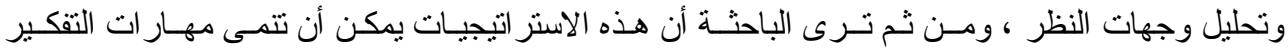

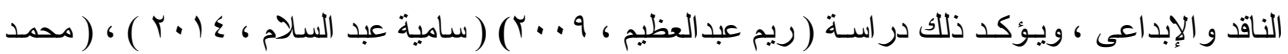


أيضأ وفى العصر الحالي نوجهت جميع الدول للإفادة من التعليم الالكترونى ، وخاصة التعلم الدمدج في تعليم الطلاب لكونه يجمع بين مز ايا التعليم النقليدي و الالكترونى ، وترى الباحثة أنه مناسب لتسهيل تتفيذ التهائ

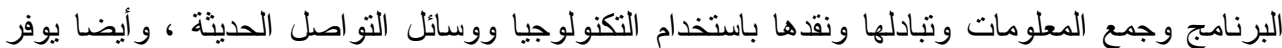
الفرصة للتعلم الذاتي ، من هنا اتضحت فكرة البحث الحالي.

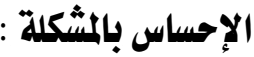

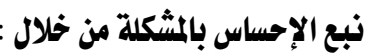

إثر اف الباحثة على طلاب التربية العملى لأعوام عديدة داخل مصر وخارجها في المملكة العربية

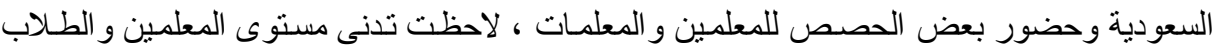
المعلمين بالفرقة الر ابعة في أداءات التدريس المنمية للتفكير الناقد و الإبداعى بالر غم من دراسة هؤلاء الطلاب لعدة مقرر ات في مهار ات وطرق التدريس. اجر اء مقابلة بعض أعضاء هيئة التدريس و الموجهين المشرفين على التربية العملية في كليات التزبية

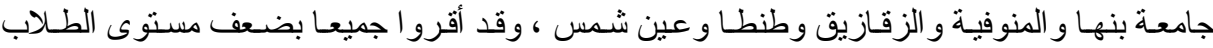

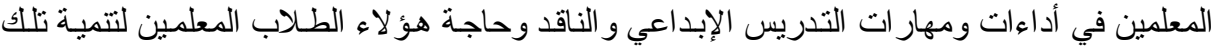

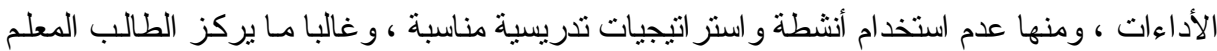
على طريقة المحاضرة وقليلا من المناقتة ، و لا يعطى للطلاب فرصة للتفكير في الحل و لا يهتم بتقديم

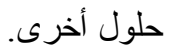
تأكيد الأدبيات و الدر اسات السابقة على ضرورة تتمية تلك الأداءات لدى المعلمين و الطلاب المعلمين

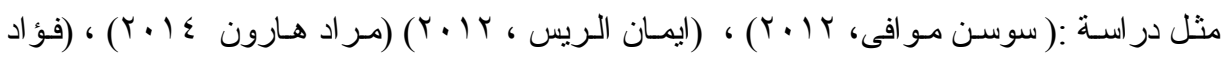

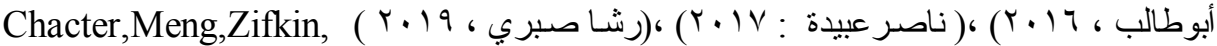
(Hossine:2016) ،(Jeffrey Troman, 2013) ، (2006) فاعلية استر اتيجيات التعلم النشط و التقكير المتنـعب في تتمية مهار ات التفكير الناقد و الإبداعى للى التى

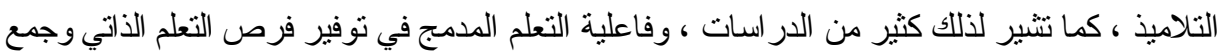
المعلومات وتبادلها ونقدها عبر وسائل التعلم الالكترونى المختلفة.

\section{مشكلـــة البحســـث}

تحددت مشكلة البحث في تدنى مستوى الطــلاب المعلمين بشعبـة رياضيات في أداءات التدريس ( المنمية لمهار ات التفكير الناقد و الإبداعى ) ، ومن ثم سعي البحث للإجابة عن الأسئلة التالية : 
1 ـ ماأداءات تتمية مهار ات التفكير الناقد و الإبداعى المناسبة للطلاب المعلمين بشعبة رياضيات؟ r ـ ما البرنامج المقترح القائم على النعلم النشط و التفكير المنتـعب لتنمية مستوى الطلاب المعلمين بشعبة رياضيات في أداءات تتمية مهار ات التفكير الناقد و الإبداعى؟ الفئ الفئ بـ ما فاعلية البرنامج المقتر ح في تتمية تلك الأداءات؟

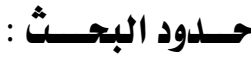

- عينة من الطلاب المعلمين بشعبة الرياضيات الفرقة الر ابعة عام بكلية التربية بينها مقر عمل الباحثة

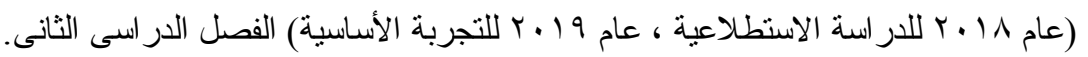

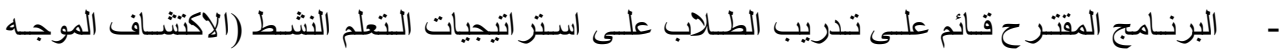

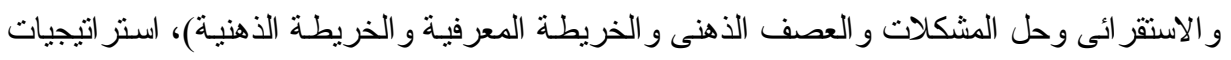

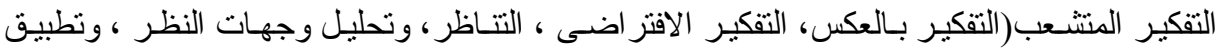
الأنظمة الرمزية). - يقتصر البرنامج على أداءات التصريس المتوقع تتميتها من خلال تطبيق البرنامج.

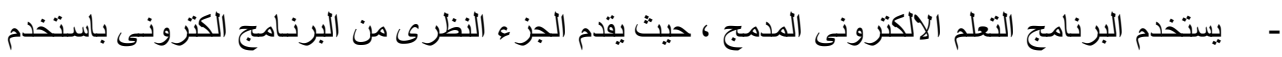

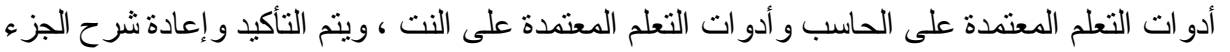

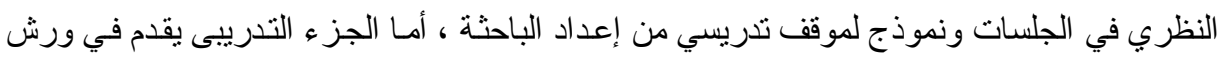
التشريس المصغر ، وترسل فيديو هات من فصول التربية العملى للباحثة من خلال ( التليجر ام ، الفيس ،

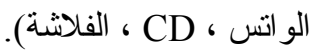
- - قياس الفاعلية باستخدام اختبار ت ، حجم الثأثير.

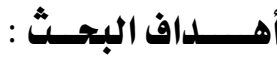 يهذف البحث الى :}

- إعداد قائمة أداءات التذريس المنمية لمهار ات التفكير الناقد و الإبداعي و المناسبة للطلاب المعلمين بشعبة

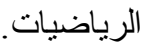
- إعداد برنامج لتتمية أداءات التدريس المنمية لمهار ات التفكير الناقد و الإبداعي و المناسبة للطلاب المعلمين بشعبة الرياضيات. ـ ـ التعرف على فاعلية البرنامج المقتر ح في تتمية أداءات التنريس المنمية لمهار ات التفكير الناقد و الإبداعي و المناسبة للطلاب المعلمين بشعبة الرياضيات الئرئ. 
1 ـ قائمة أداءات التدريس المناسبة لتتسية مهار ات التفكير الناقد و الإبداعى للطلاب المعلمين بشعبة رياضيات

$$
\text { (إعداد الباحثة). }
$$

r- البرنامج المقتر ح (إعداد الباحثة).

rــ اختبار في الجانب المعرفى للبرنامج و أداءات تتمية مهار ات التفكير الناقد و الإبداعى (إعداد الباحثة). ع - بطاقة ملاحظة لأداءات التدريس المنمية لمهار ات التفكير الناقد و الإبداعى (إعداد الباحثة).

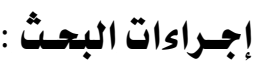

$$
\text { ـ در اسة نظرية عن التعلم النشط و التفكير المتشعب }
$$$$
\text { ـ در اسة نظرية عن التفكير الناقد و الإبداعى }
$$

ـ در اسة نظرية عن أداءات الندريس المنمية لمهار ات التفكير الناقد و الإبداعى

- إعداد قائمة بأداءات التنريس المنمية لمهار ات التفكير الناقد و الإبداعى و المناسبة للطلاب المعلمين بالفرقة

$$
\text { الر ابعة شعبة رياضيات }
$$

- إعداد بطاقة ملاحظة لأداءات التدريس المنمية لمهار ات التفكير الناقد و الإبداعى و اللازمة للطلاب المعلمين

$$
\text { بالفرقة الر ابعة شعبة رياضيات }
$$

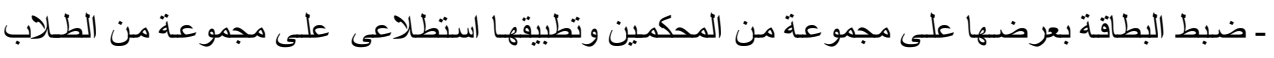

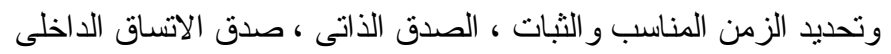

$$
\text { - إعداد أسس بناء البرنامج المقترح }
$$

ـ تصميم البرنـامج المقتر ح لتتميـة أداءات التـدريس المنميـة لمهار ات التفكير الناقد و الإبـداعى و المناسبة للطلاب المعلمين بالفرقة الر ابعة شعبة رياضيات و عرضاء الفها على مجمو عة من المحكمين

$$
\text { - إعداد اختبار معرفى في محتوى البرنامج وضبطه }
$$

ـ اختيار عينة البحث من طلاب الفرقة الر ابعة بشعبة رياضيات

ـ تطبيق البطاقة و الاختبار قبليا

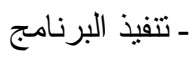

ـ تطبيق البطاقة و الاختبار بعديا ، رصد النتائج وتفسير ها وتقديم التوصيات و المقترحات 
يستخدم البحث المنهج الوصفى في الدراسة النظرية و التحليلية للبحث و إعداد أداتى البحث وتفسير

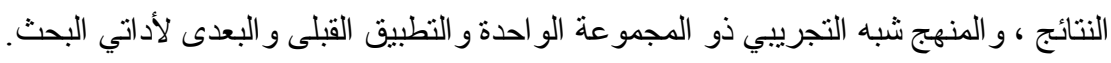

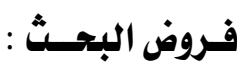

1- يوجد فرق دال احصائيا عند مستوى (0. ., · ) بين متوسطى درجات مجموعة البحث قبليا وبعديا في الجانب المعرفى للبرنامج لصالح التطبيق البعدي.

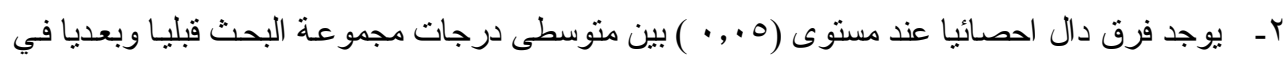

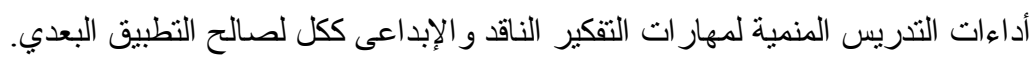

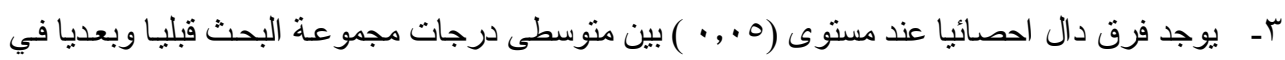

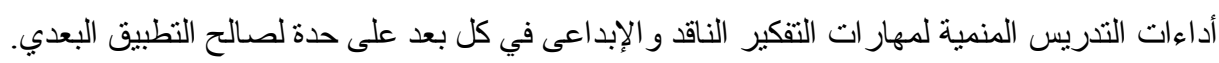
ع- - البرنامج بجانبيه المعرفى و الأدائى له نأثير وفاعلية كبيرة في تتمية لتلك الأداءات.

\section{أهميــة البحسثـث :}

\section{تتبع أهمية البحث من خلا ما يمكن أن يفيد به كما يلى :}

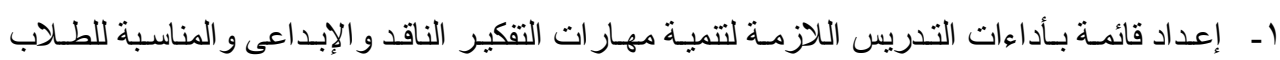

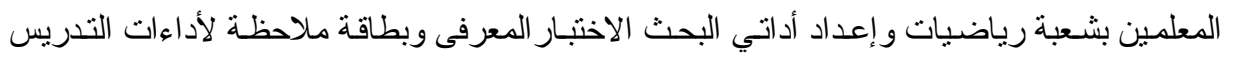

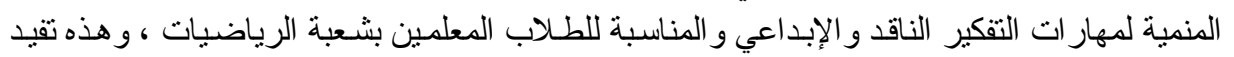

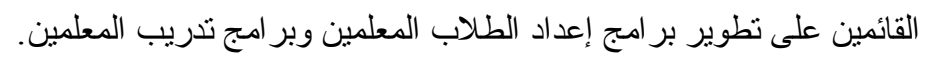

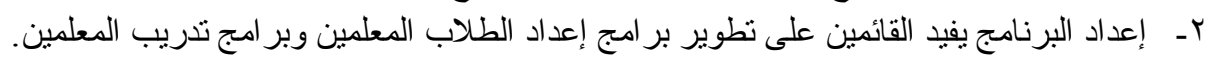

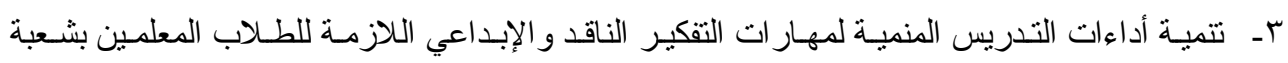
الرياضيات. ع- فتح المجال لبحوث أخرى للباحثين و الإفادة من الاطـار النظرى وكيفية إعداد أدوات البحث ونتائج

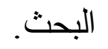

\section{مصطلحسات البحثث :}

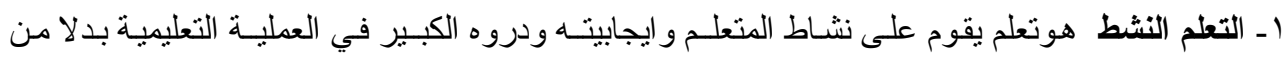

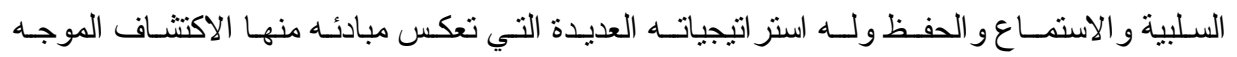
و الاكتثاف ( الاستقر ائى و الاستتباطى ) و العصف الذهنى وحل المشكلات و الخر ائط الذهنية و المعرفية الذانية 
r- التفكير المتثعب : التفكير المتشعب هو نمط من أنماط التفكير يؤدي ممارسته ، و التدريب عليه إلى حدوث وصلات جديدة بين الخلايا العصبية ، مما يدعم بناء أنسجة عصبية في شبكة الأعصاب للادماغ.

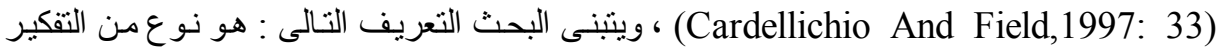
المرن يؤدي التدريب عليه وممارسته إلى توليد الأفكار و الاستجابات المختلفة لموقف أو مشكلة مـا،

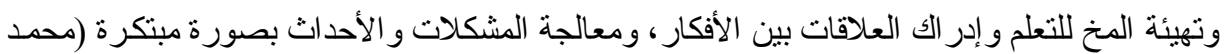

rـ أداءات التدريس: تعرفها الباحثة بأنها كل السلوكيات اللفظية وغير اللفظية التي يقوم بها الطالب المعلم داخل الفصل من أجل تحقيق أهداف التنريس بفاعلية و اتقان.

عـ أداعات تنمية مهار ات التفكير الناقد والإبداعى تعرفها الباحثة بأنها كل السلوكيات اللفظية وغير اللفظية

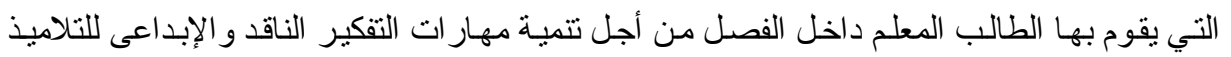

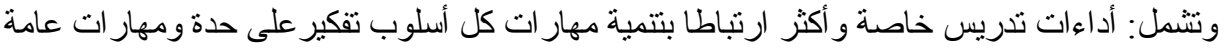
تصلح بل ويجب نو افر ها لتتمية أبا منهما وتتمنل في البيئة التعليمية المناسبة. هـ التفكير الناقد : هو عملية استتاجية تشتمل على تحليل المشكلة ومر اجعة مكوناتها وتقويمها وفق أسباب

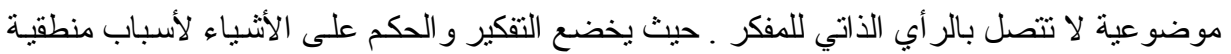

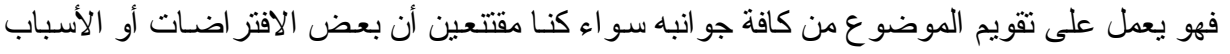

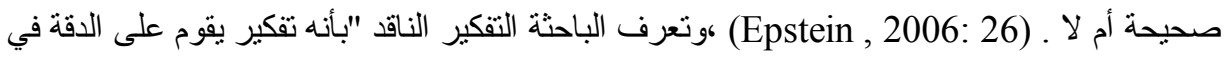

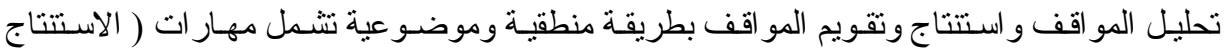
و الاستتباط و التفسير وتقويم الحجج و الهناقتشات و التتبو ء بالافتر اضات ) .

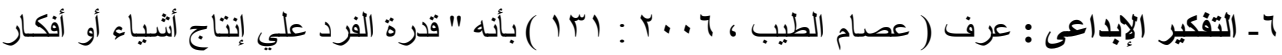

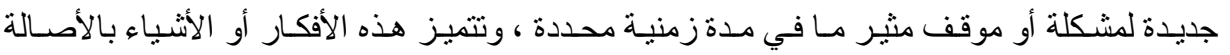

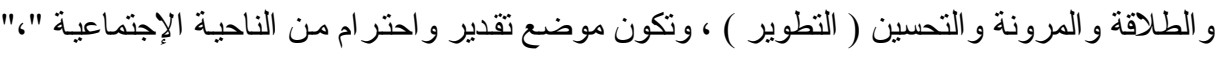

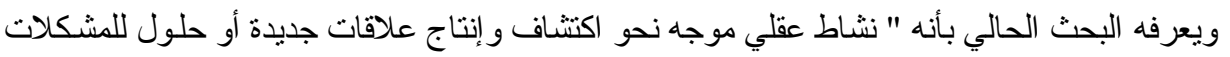
الرياضية بحيث تثميز بالطلاقة و المرونة و الأصسالة ".

\section{Critical Thinking أولاً : التفكير الناقطد}

مفهوم التفكير الناقد يعرف بأنه "عملية اسنتتاجية تتشتل على تحليل المشكلة ومر اجعة مكوناتها وتقويمها وفق أسباب موضوعية لا تتصل بالر أي الذاتي للمفكر ـ حيث يخضع التفكير و الحكم على الأشياء

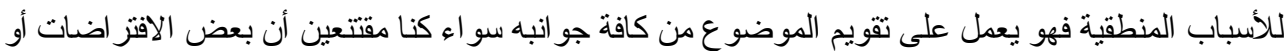




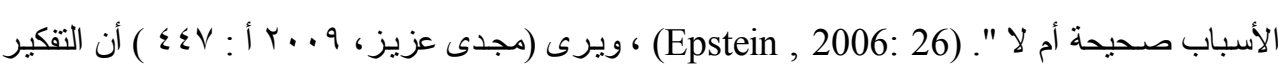

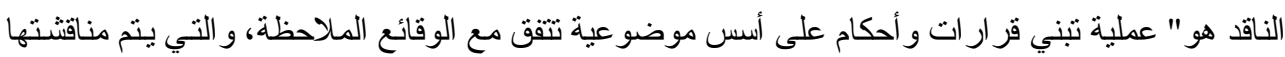

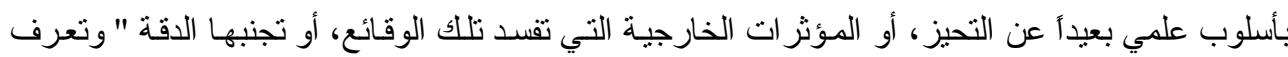

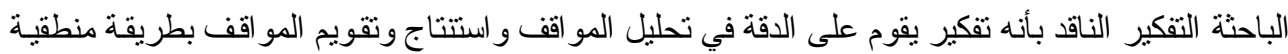

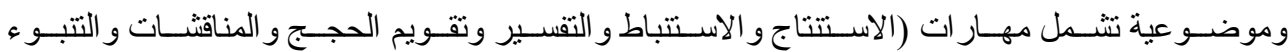
بالافتر اضات).

مهارات التفكير الناقد ويؤكد الكثبر من التربويين على أن المهارات الرئيسية للتفكير الناقد هى:

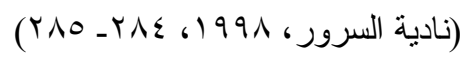
- ـ - مييز الفرضيات وتعريف غير الو اضح منها. استتباط واستخلاص المعلومات. التمييز بين الحقيقة و الر أى و الادعاء.

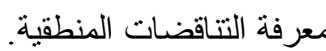
التمييز بين المعلومات الضرورية وغير الضرورية. القدرة على التنبؤ.

تحديد دقة الخبر و استيعابه و التأنى فى الحكم عليه.

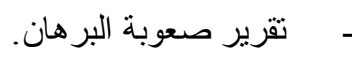
-

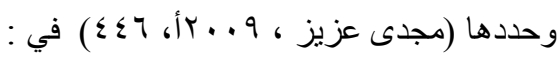

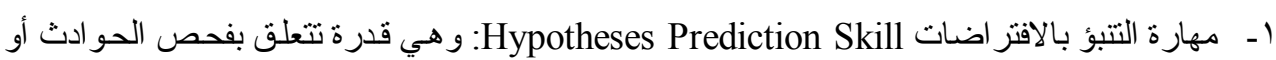

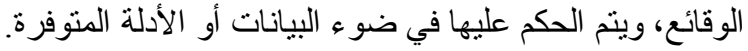

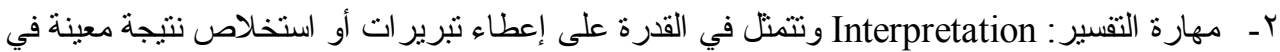
ضوء الوقائع، أو الحو ادث المشاهدة التي يقبلها العقل الإنساني. rـــ مهارة تقويم المناقثنات Evaluation Discussions: وهي تلتمثل في قدرة المتعلم على التمييز بين

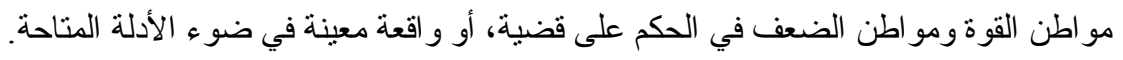

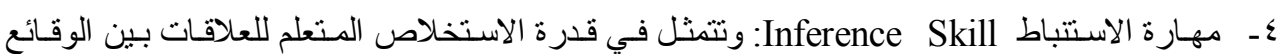

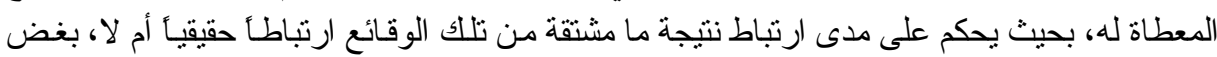


○ـ ـ مهارة الاستتناج Deduction Skill: ونتمنل في قدرة المتعلم على التمييز بين درجات احتمال صحة أو خطأ نتيجة ما تبعأ لدرجة الارتباطها بوقائع معينة معطاة.

و الاستتتاج يعرف بأنه التفكير فيما هو أبعد من المعلومات المنو فرة لسد الثغر ات فيها ـ (فنحى جروان،

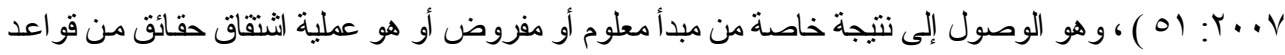

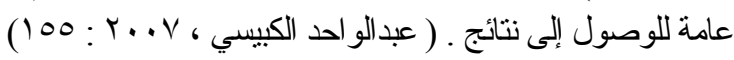

\section{خصائص المتعلم ذو التفكير الناقلد}

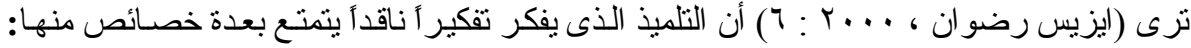

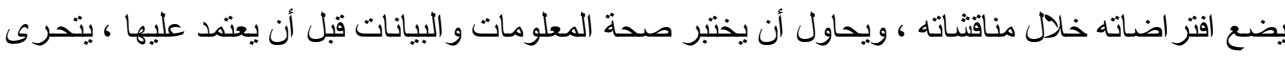
الدقة فى الحصول على المعلومات و البيانات من مصـادر ها الأصلية، بطبق قو اعد الاستـلال المنطقى فى التى

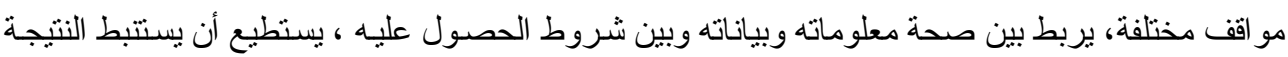

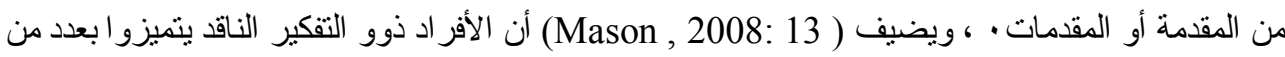

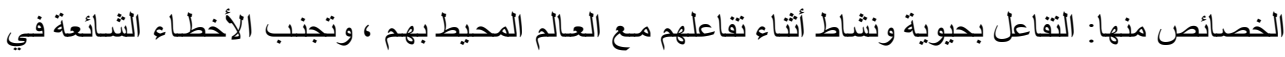

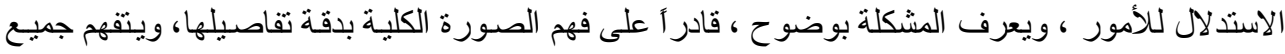

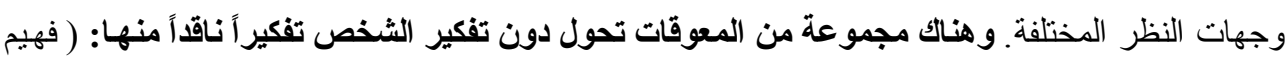

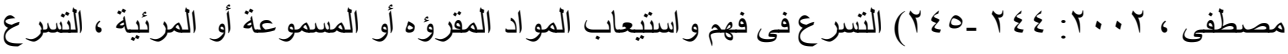

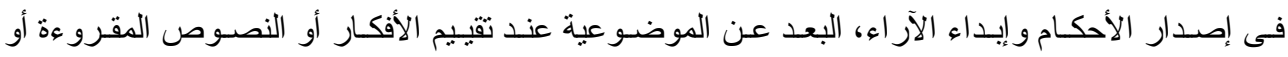

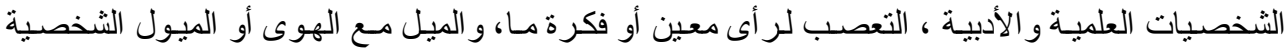

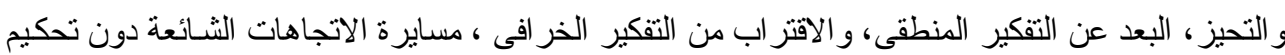

$$
\text { العقل، التفكير الروتينى أو التفكير الجامد المحدود. }
$$

التدريس من أجل تنمية مهارات التفكير الناقد يقصد به التدريس الذى ينمي مهار ات التفكير الناقد

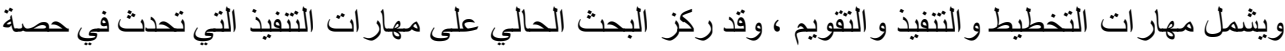

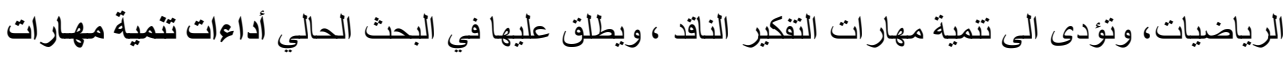

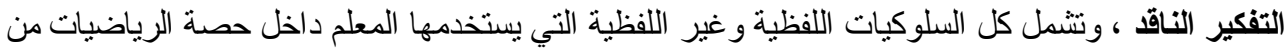

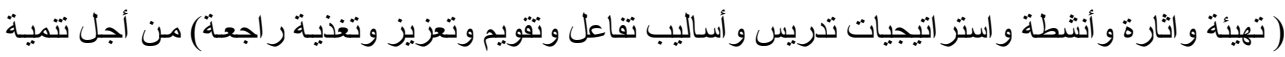

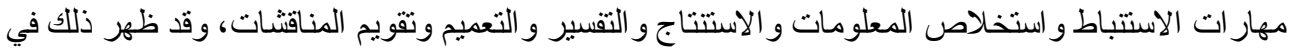

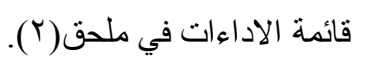

دور المعلم في تنمية مهارات التفكير الناقد يستطيع معلم الرياضيات أن ينمى مهار ات التفكير الناقد بتوفير بيئة تعليمية مناسبة تتشمل استخدام تهيئة و أنشطة و استر اتيجيات تدريس مناسبة و أسئلة ومشكلات 


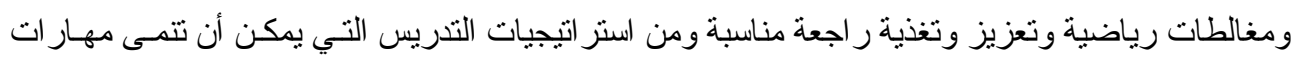

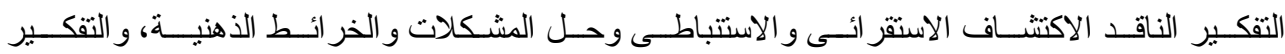

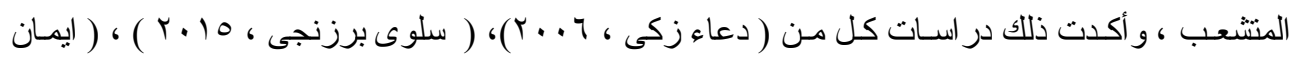

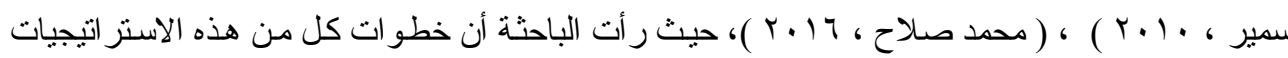

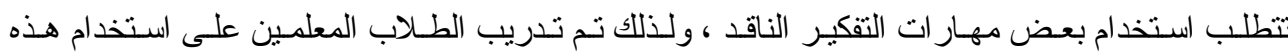

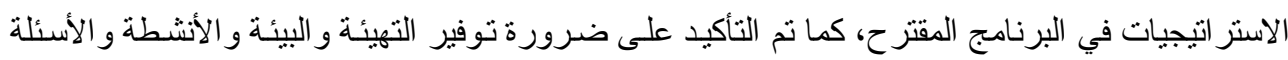
المناسبة.

\section{تعليق عام على هذا البعد :}

\section{استفادت الباحثة من هذا البعد في :}

ـ التعرف على طبيعة وخصائص ومهار ات التفكير الناقد التي يسعى البحث الحالي الى إعداد قائمة بالأداءات التذريسية اللازمة لتنميتها ـ تحديد الأداءات التدريسية اللازمة لتتميتها ـ تحديد استر اتيجيات التشريس المناسبة لتتمية مهار ات التفكير الناقد ـ التعرف على بعض الأنشطة و الاسئلة المناسبة لتتميها ـ ـ التعرف على أدو ار المعلم وبيئة التعلم المناسبة لتتميتها ـ ـ التعرف على خصائص التلميذ المفكر الناقد ومعوقات التفكير الناقد وقد تم انعكاس ذلك في تحديد أسس البرنامج المقتر حو إعداده وتتفيذه ،ومن الدر اسـات التي تناولت

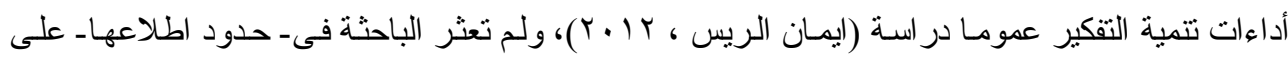
در اسة واحدة عربى أو أجنبى تتاولت أداءات تتمية مهار ات التفكير الناقد.

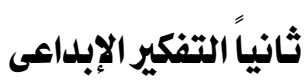

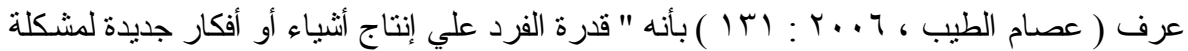

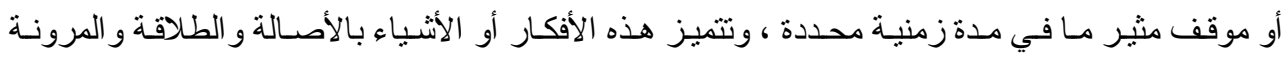

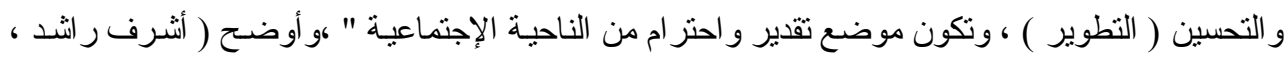

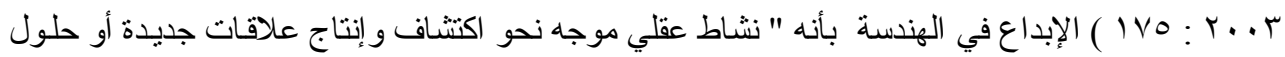
متتو عة للمشكلات الهندية بحيث تتميز بالطلاقة الثكلية و الطلاقة الفكرية و المرونة و الأصالة ". 
و عرف "هو لاندس" الإبداع فى الرياضيات على أنه" المرونة التى يظهر ها الطالب عندما يستخدم

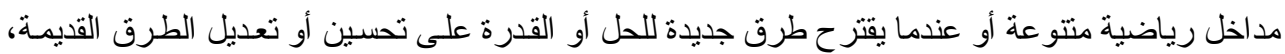

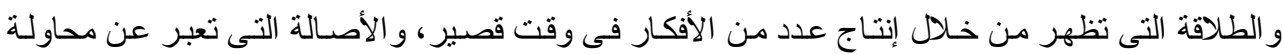

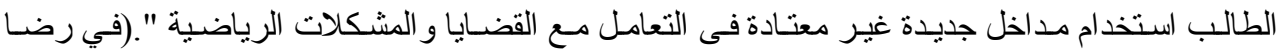

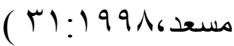

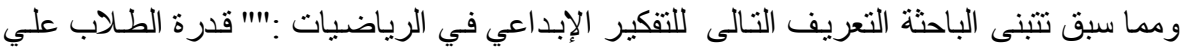
اكتثاف علاقات ونظريات جديدة و إنتاج أفكار أو حلول للمشكلات، وتتميز هذه الأفكار أو الحلول بالطلاقة الألة

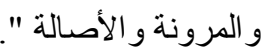

\section{وفيما يلي عرض تفصيلي لمهارات التفكير الإبداعي :}

() اكتثاف علاقات رياضية جديدة : يقصد بها اكتثاف نظريات وقو انين وتعميمات جديدة بالنسبة له له

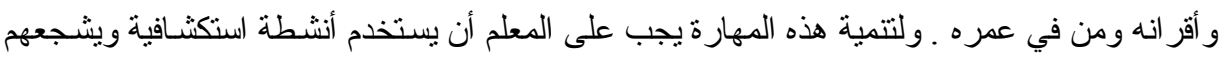
على التفكير و اكتثاف القو انين و النظريات و التععيمات ، كما يجب استخدام استر اتيجيات تدريس تحثنهم

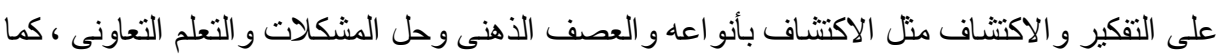
يجب أن يستخدم التعزيز المناسب، وير اعى الفروق الفردية في تقديم التقويم المناسب لكل فئَة من التلاميذ ، ويوفر البيئة التعليمية المناسبة. Y الطلاقة : Fluency يعرفها جيلفورد بأنها " القدرة علي إنتاج أكبر عدد من الأفكار في موقف معين

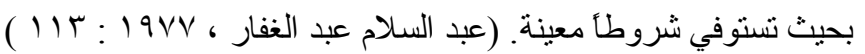

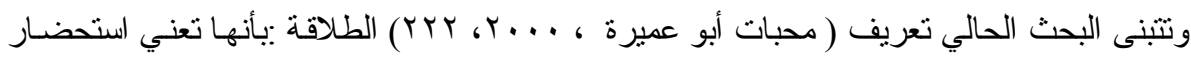

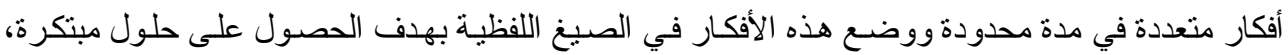
و الطلاقة منها اللفظية و الارتبياطية و الفكرية و الثنكلية ....." ويمكن للمعلم أن بسـاعد طلابه ، ليكونو ا أكثر طلاقة في التفكير أثثاء تعلمهح ، من خلال إعطاء

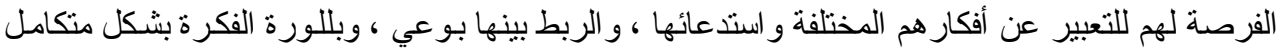

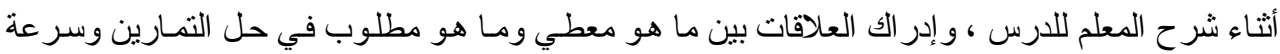

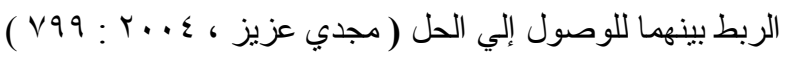

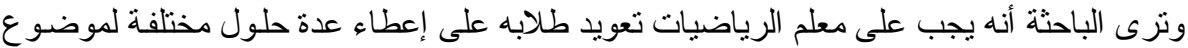

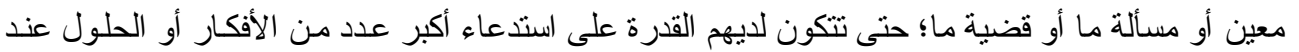

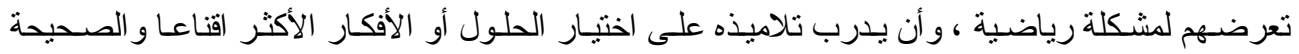




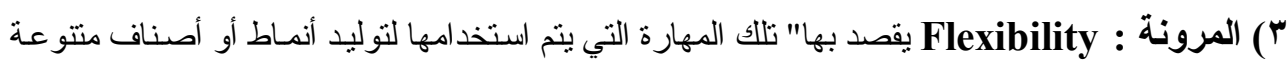

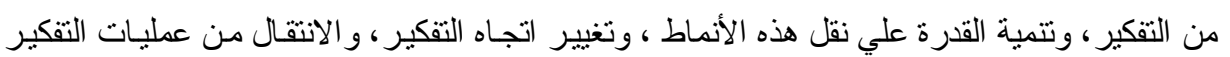

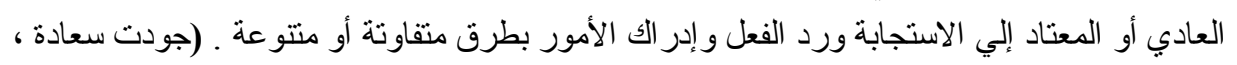

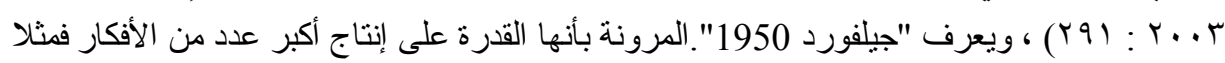

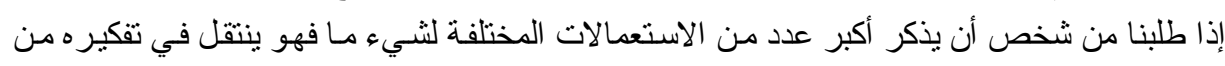

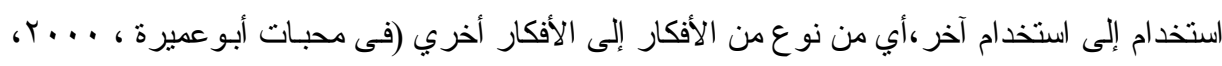

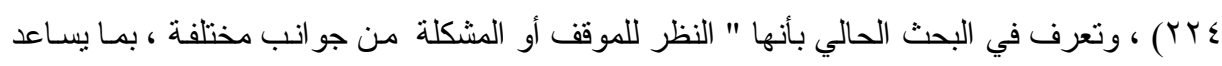

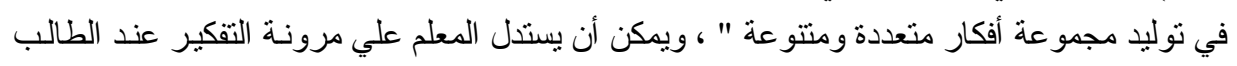

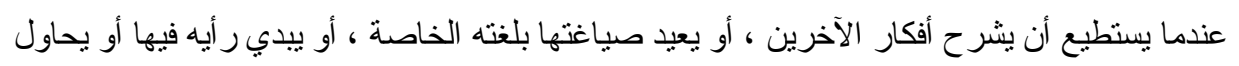

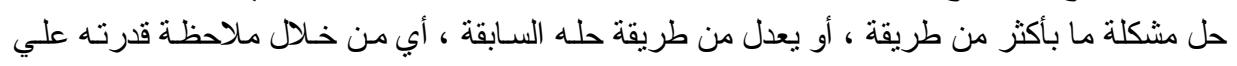

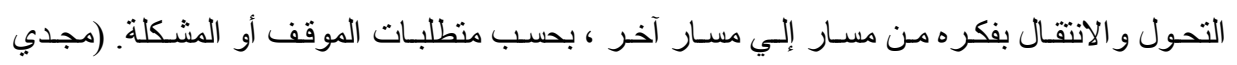

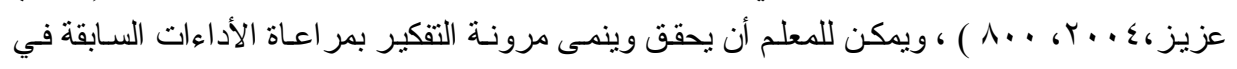
تدريسه . ع) الأصالة : Originality : يرى بلومبرى (bloombery,1973) أن الأصالة هي القرة على إنتاج

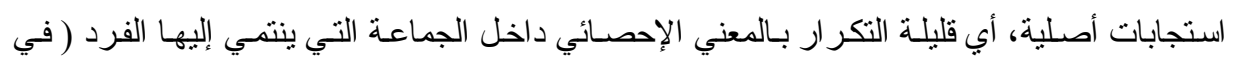

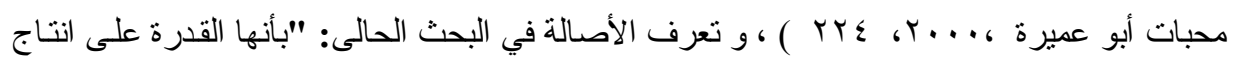

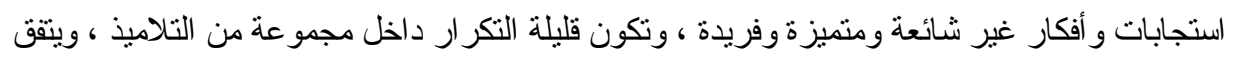

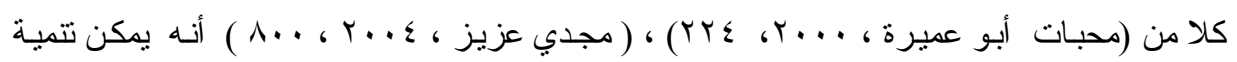

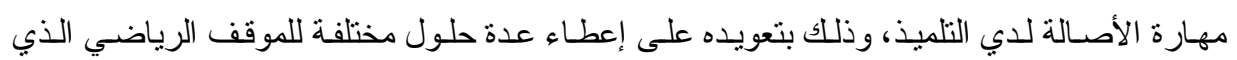

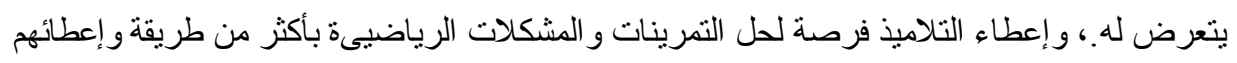

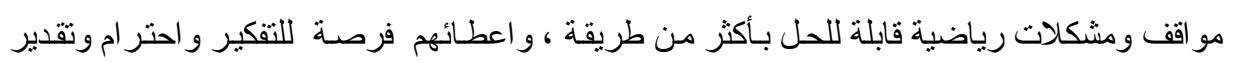

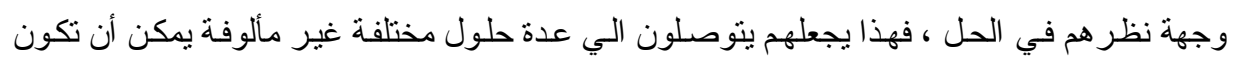

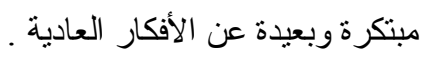

\section{خصائص ودور معلم الرياضيات في تنمية التفكير الإبلاعى :}

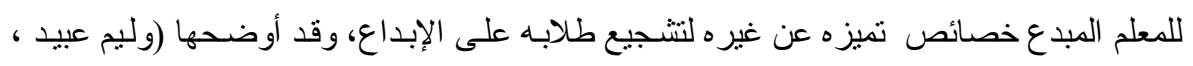

: L (1)

- يكون لديه إعداد وتتمية مهنية محفزة لذلك

- يمتلك المرونة العقلية للتكيف مع المو اقف و التعامل مع الطلاب مختلفى القدر ات و الاستعدادات 
ـ عند تقديم المعارف الجديدة يعطى أمثلة و لا أمثلة ويطلب أيضا من الطلاب تقديم أمثلة و لا أمثلة ـ يمتلك الثقة بنفسه وقدر اته ويشجع طلابه على اطلاق طاقاتهم الفكرية وتقديم أفكار متجددة ـ يكون ميسر لعملية التعلم وموجها ومرشدأ ور اعيأ واعياً.

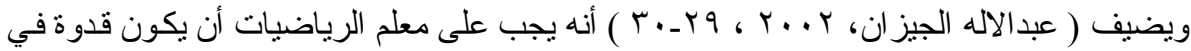

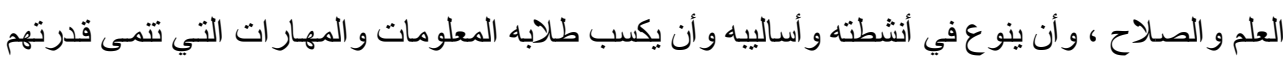
على الإبداع ، كما يجب عليه أن ينمى حب الاستطلاع و الثقة بالنفس لاى طلابه و أن يكون لديه خلفية و اسعة

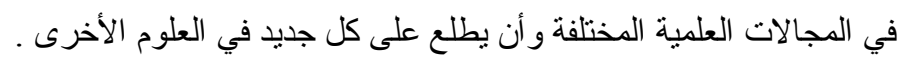
بالإضافة الى ما سبق ذكره فانه يجب تطوير مهار اته التنريسية ، وتوفير بيئة تعليمية مناسبة وكما

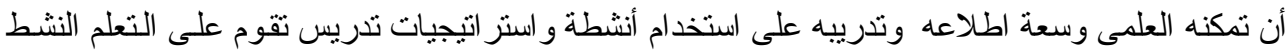

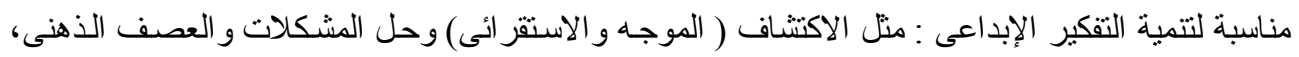

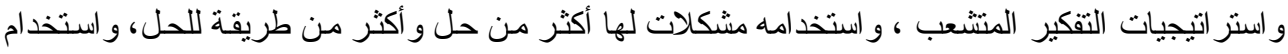

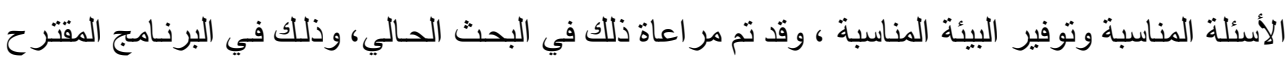
وخاصة الجزء العملى و التدريبي . التدريس الإبـاعى : يميز "جيفرى وكر افت " ( J7-78, Jevffery,B.,\&Craft, A,2004 ) بين التدريس الإبداعى و التدريس من أجل الإبداع حيث يرى ان التدريس الإبداعى يتعلق بتحقيق متعة الطلاب

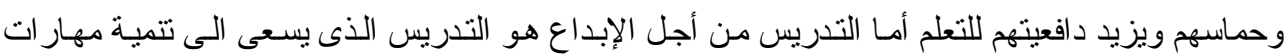

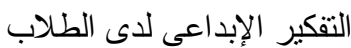

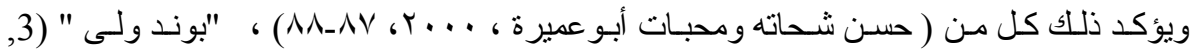

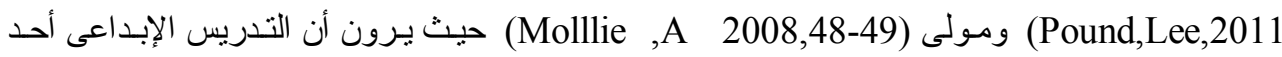
مكونـات التدريس الفعال و المتميز ، ويقوم على استخدام المدخل التخيلى لجعل التعلم أكثر اثارة حماسـا

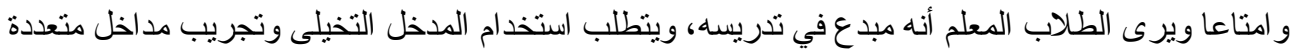
منها ( الرياضيات الحياتية و الدداخل الحسية و التجريبية ومدخل المشكلات المفتوحة ومدخل الأسئلة النوليدية

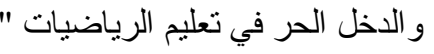

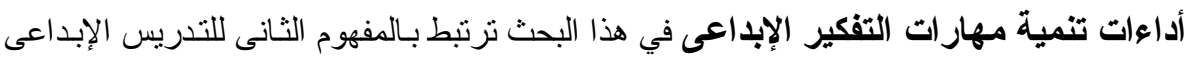

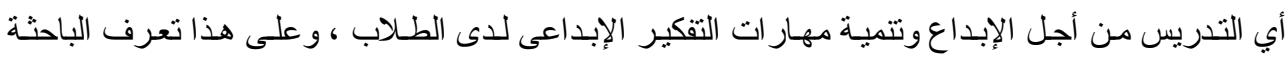

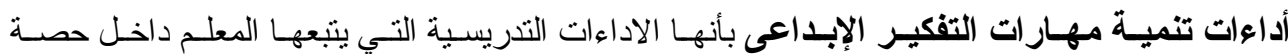


الرياضيات من أجل تتمية مهار ات التقكير الإبداعى موضع الاهتمام في البحث الحالي ونتشمل أداءات تدريس

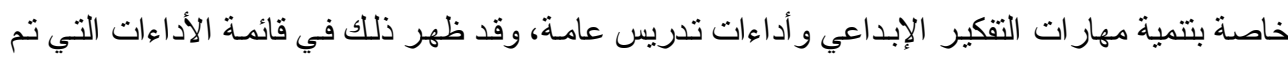
إعدادها في ملحق (r) (بادة)

\section{ثالثاً : التفكير المتشعب (Neural Branching Thinking (N B T)}

مفهوم التفكير المتثعب و هو نوع من التفكير يكون على المتعلم فيه الانطلاق بتفكيره إلى آفاق

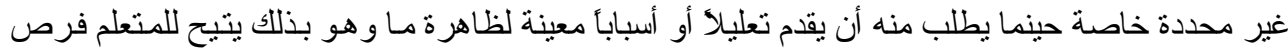

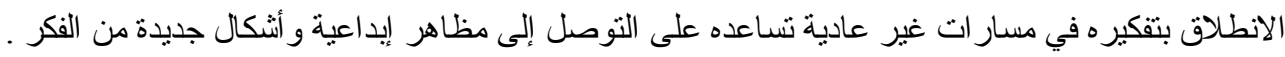

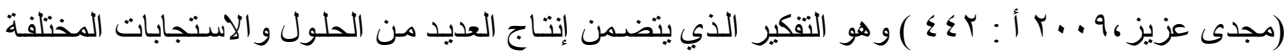

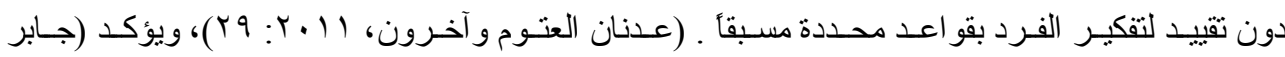

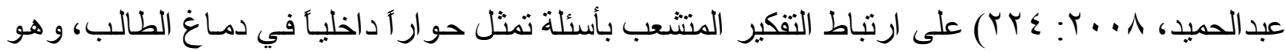

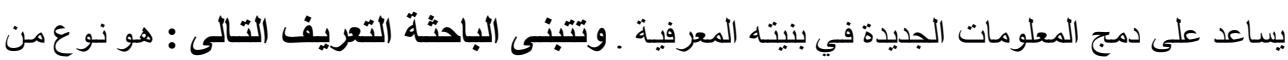
التفكير المرن يؤدي التدريب عليه وممارسته إلى نوليد الأفكار و الاستجابات المختلفة لموقف أو مشكلة مـا،

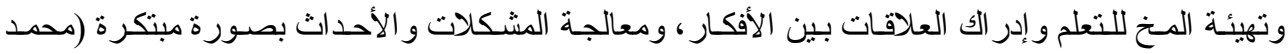

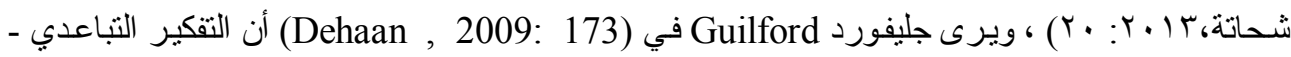

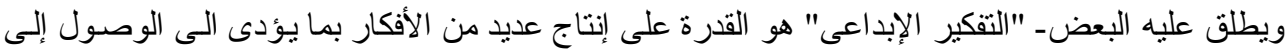

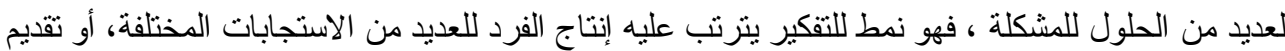

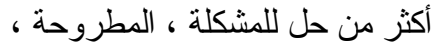

و هذا يؤكد العلاقة بين التفكير المتتعب و التفكير التباعدي ، حيث يقود كل منههـا للآخر فالتفكير

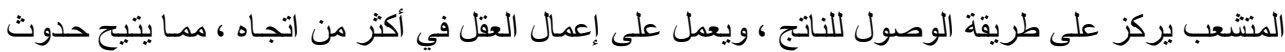
وصلات جديدة بين الخلايا العصبية ، مما يساعد في ظهور ، استجابات تباعدية نظهر فيها السيات السمات الإبداعية : بينما التفكير التباعدي بركز على الناتج التباعدي فيضع مجموعة من الحلول المناسبة للمشكلة الواحدة ويحتاج

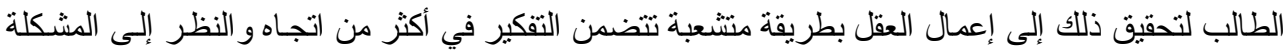
من وجهات نظر مختلفة ، مما يتيح الوصول إلى نتائج متعددة تظهر فيها لفئ السمات الإبداعية.

ب) أهمية التفكير المتشعب

يساعد التتعب في التفكير على حدوث اتصـالات جديدة بين الخلايـا العصبية، نسمح للتفكير بـأن

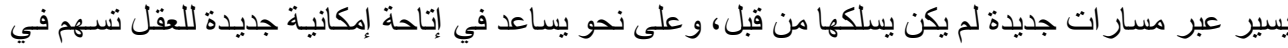

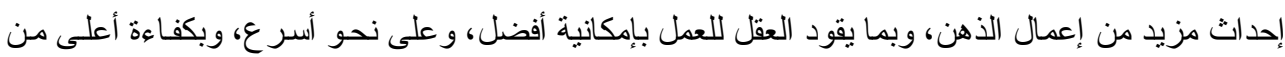




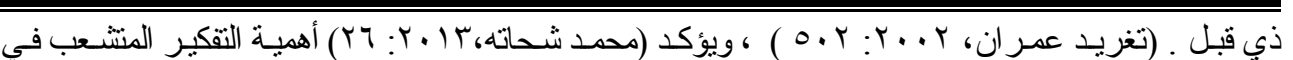

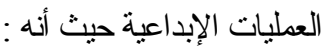

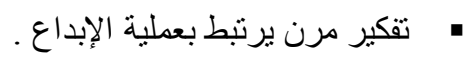

• يساعد على توليد العديد من الأفكار و الاستجابات المختلفة . ل.

• يحدث اتصالات متميزة بين الخلايا العصبية في شبكة الأعصاب في المـخ مما بسـاعد على تهيئة

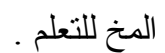

• يحدث أكبر قدر من الربط بين الأفكار و المعلومات المرتبطة بالموضوع .

\section{دeural Branching Strategies استراتيجيات التفكير المتشعب}

يرى كاردليشيو وفيلد (42-42) أن استر انتجيات التفكير

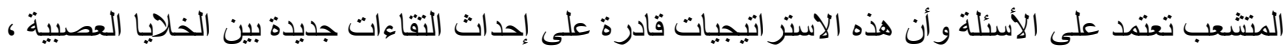

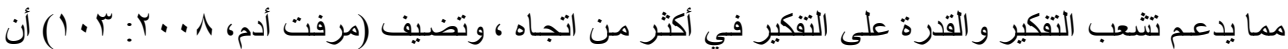
الهدف من استخدام هذه الاستر اتيجيات ليس مجرد طر ح الأسئلة و الاستماع إلى إجابات الطلاب ، بل توظيف

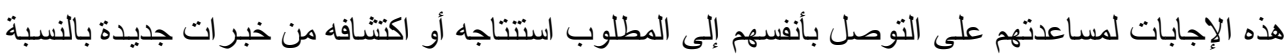

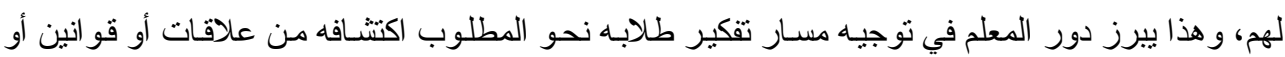
تعميمات رياضية جديدة ، وفيما يلى توضيح للاستر اتيجيات التي بستخدمها البحث الحالي :

\section{Hypothetieal Thinking Strategy إستراتيجية التفكير الافتراضي}

تعتمد هذه الاستر اتيجية في جوهر هـا على توجيه المعلم لمجموعة من الأسئلة الافتر اضية للطلاب و التي تدفعهم للتفكير في الأحداث و العو اقب و النتائج المترتبة عليها، و على المعلم توظيف إجابات الطلاب في توجيههم نحو اكتثاف علاقات جديدة أو التوصل لقو انين محددة أو استتناج تعميم. Cardellichio and) Field , 1997: 39 ، وتساعد الأسئلة الافتر اضية الطلاب على التفكير في الأحداث و النتائج المترنبة عليها و اكتثاف علاقات جديدة، مما يؤدي إلى تعديل مسار ات التفكير ونوجيهها نحو اكتنتاف الحلول و العلاقات بين مكونات الموقف المشكل ـ (و ائل عبد الله، و . . ؟: ـ • () ، و الأسئلة الافتر اضية تعتمد على توجيه سؤ ال للطالب يحمل جملة افتر اضية مثل ماذا يترتب على زيادة عرض المستطيل ليتساوى مع طوله ؟ وهو ما يدفع المتعلم نحو التفكير بصورة متثعبة تساعده على الربط بين الأشياء المختلفة ويعطل على تتمية الخيال لديه ،

$$
\text { ومن أمثلتها في الرياضيات }
$$




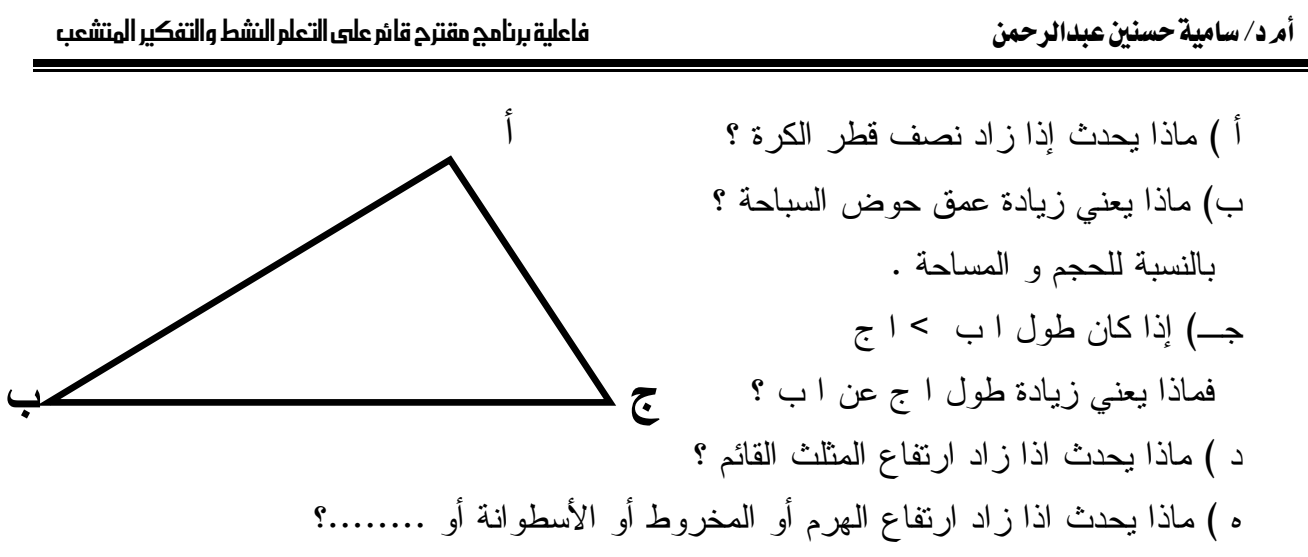

إستراتيجية التفكير العكي (Reversal Thinking Strategy)

توفر استر اتيجية التفكير العكسي مزيداً من فرص تعميق رؤية المتعلم للأحداث و المو اقف و التفكير

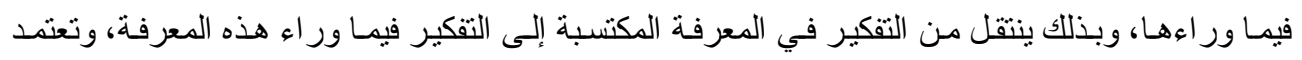

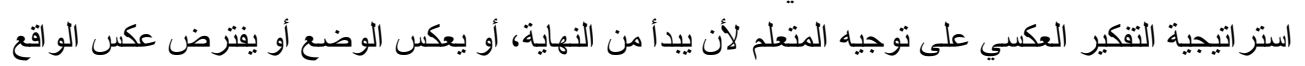

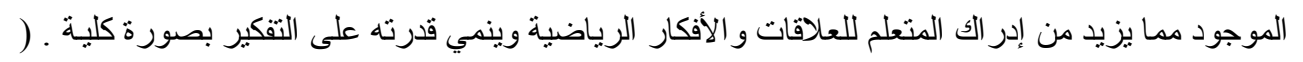

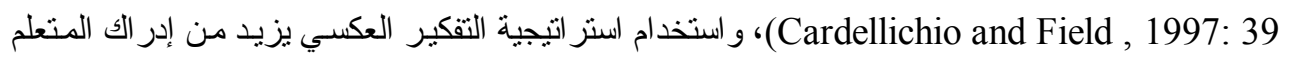

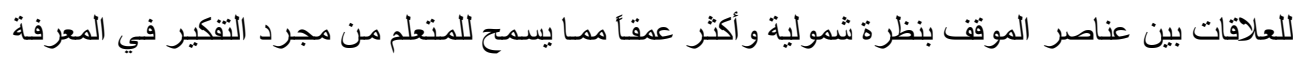

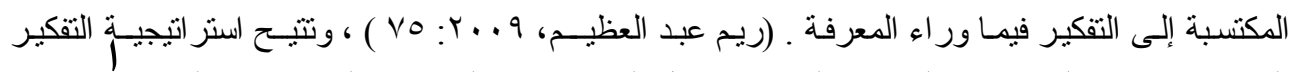

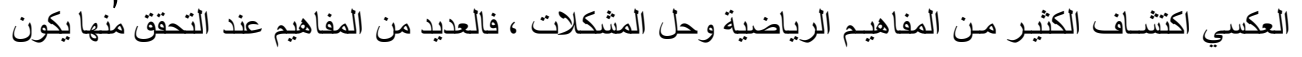

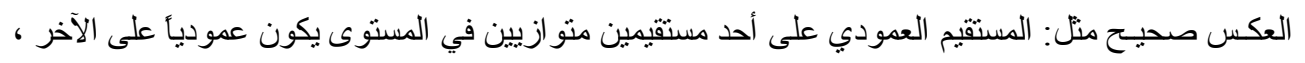

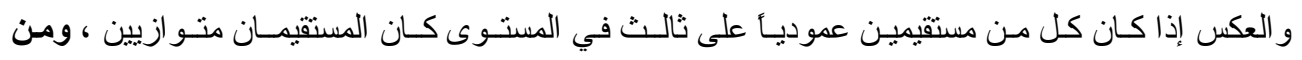
أمثلتها في الرياضيات أذان

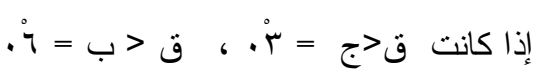

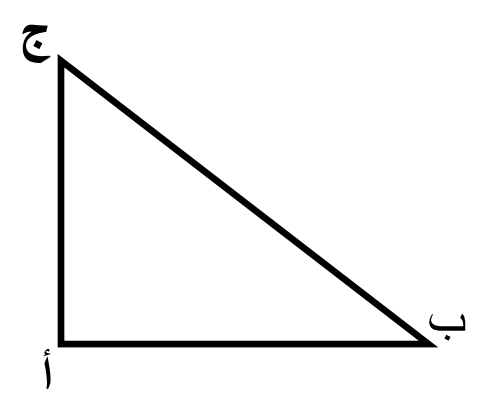

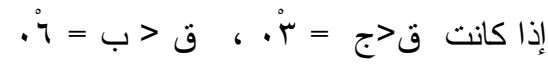

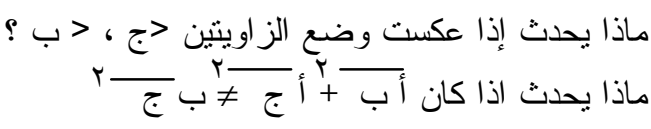

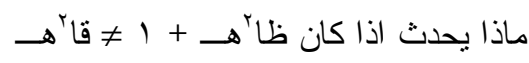

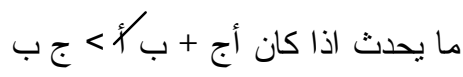

إستراتيجية تطبيق الأنظمة الرمزية المختلفة 


\section{(Application of Different Symbol Systems Strategy)}

تعتمد استر اتيجية تطبيق الأنظمة الرمزية على استخدام الرموز المختلفة في مو اقف التعلم، فزيادة

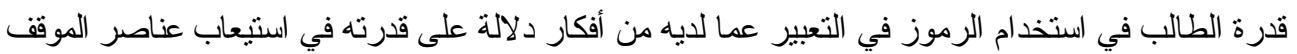
التعليمي، و التعبير عنه بأسلوبه. ( 40 :Cardellichio and Field , 1997)، وتسـاعد استر اتيجية الأنظمـة فئس

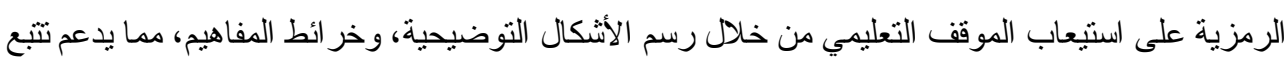

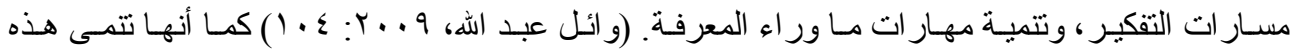

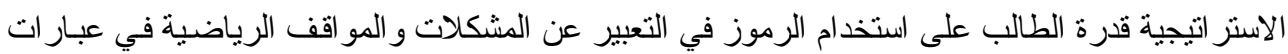

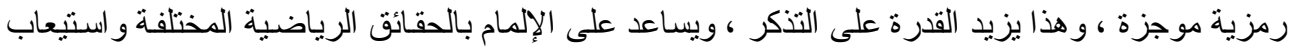
عناصر الموقف و إدر الك العلاقات بين أجز ائه .

\section{إستراتيجية التناظر (Analogy Strategy)}

توفر استر اتيجية التناظر فرص البحث عن العلاقات بين الأشباء، لتحديد أوجه التشابه و الاختلاف فهى تنمح للعقل أن يقارن بين الأثياء و العلاقات مما يزيد من فرصة تشعب التفكير لدى الطلاب حيث يساعد البحث عن أوجه التتاظر بين أثنياء تبدو منتـابهة . (Cardellichio and Field , 1997: 40 ) ، وتعنمد استر اتيجية التتـاظر على تتشيط القدر ات الذهنية لدى الطالب وذلك من خـلال توفير دعم فرص البحث و التقصي عن العلاقات و الرو ابط بين الأشياء، وتحديد أوجه التتـابه و أوجه الاختلاف بينههـا، و البحث عن التتاظر و التماتل بين الأشياء يعمل على دفع العقل إلى المزيد من تتعب التقكير وتتمية القدرة على الربط بين

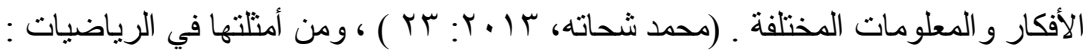

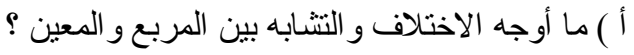
ب) ما أوجه الاختلاف و التشابه بين تشابه وتطابق مضلعين؟ ج) قارن بين الأشكال الناتجة من عمليات الدور ان و الانتقال و الانعكاس لقطعة مستقيمة ؟

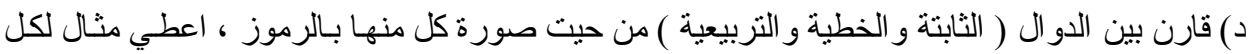

$$
\text { منها ، ارسم هذه الأمثلة }
$$

هـ) ما أوجه التتشابه و الاختلاف بين كل من منو ازي المسنطبلات و المكب و المنشور ؟

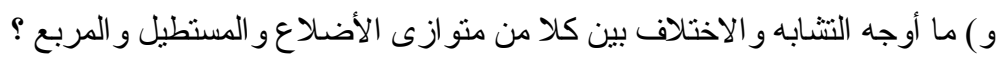

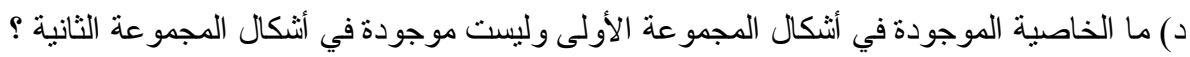


المجموعة الأولى :
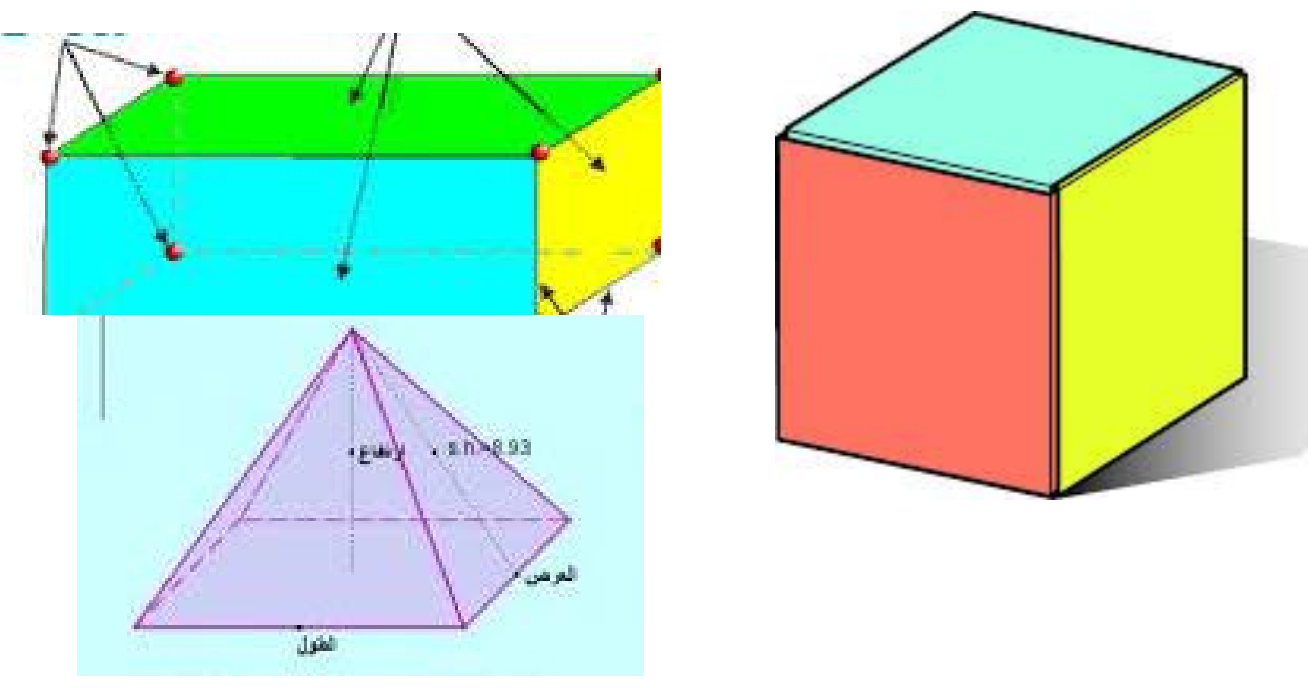

المجموعة الثانية :
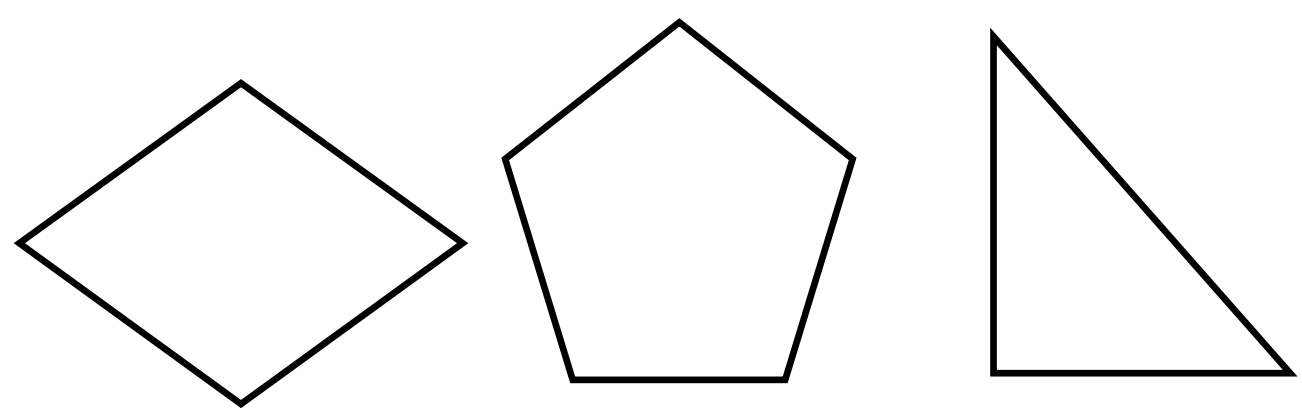


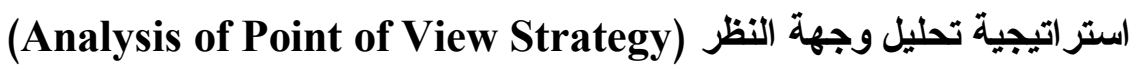
تسمح استر اتيجية تحليل وجهة النظر للطالب أن يعيد التفكير في آر ائه ومعتقداته حيث تعتمد هذه

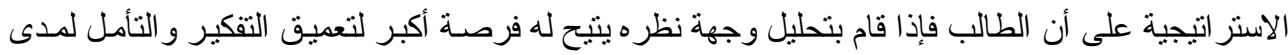

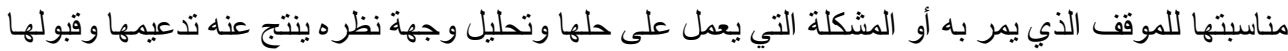
أو تعديلها أو رفضها ـ (Cardellichio and Field, 1997: 41)

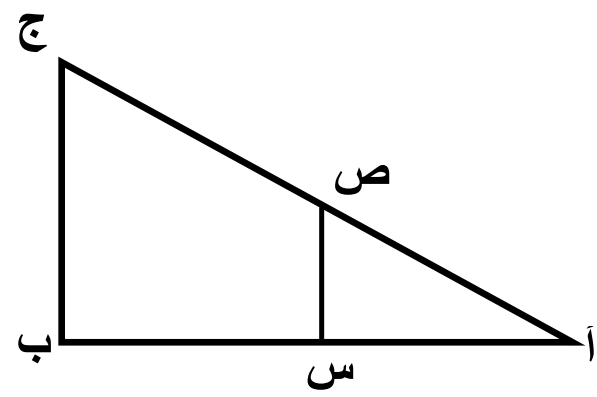
ومن أمثتنها في الرياضيات

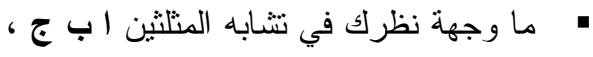

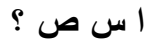

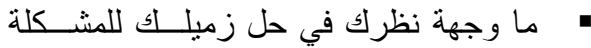
السابقة

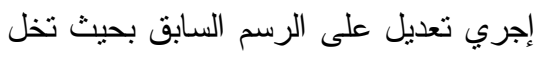

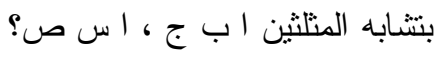

\section{و) أهمية استراتيجيات التفكير المتشعب في تدريس الرياضيات}

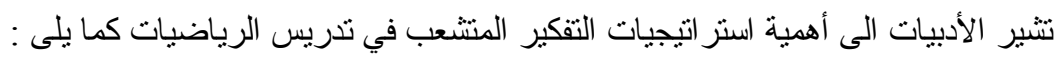

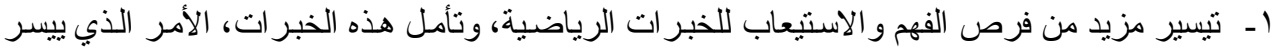

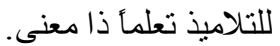
r- تيسير فرص إعمال العقل، وتعدد الرؤى، وتتبع مسار ات التفكير ، و التحكم فيها وتعديلها.

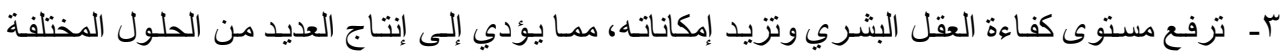
لل للمشكلة الرياضية.

عـ تنمي القدر ات الذهنية وتعزز بناء الوصلات بين الخلايا العصبية.

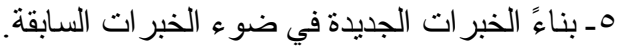

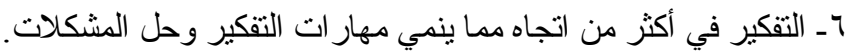

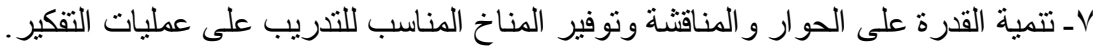
1- زيادة فرصة الوصول إلى حلول إبداعية للمشكلات. 9ـ نوفير عناصر التثويق و المتعة في البيئة التعليمية وزيادة ثقة الطلاب في في أنفسهم. ومن الدراسـات التي أكدت فاعلية التفكير المتتـب في تعليم الرياضيات در اسـة كون و آخرون نوصلت الى فاعلية البرنامج القائم على التفكير المتتعب في تنمية التفكير الإبداعي 
في الرياضيات لدى التلاميذ ذوي الاحتياجـات الخاصـة بالصفين الخامس و السـادس بالمرحلة الابندائية ، ودر اسـة (Unal And Demir , 2009) ، تمنلت أهم نتائجها في فاعلية استخدام استر انتجيات التفكير المتثـعب في تتمية التحصيل في الرياضيات، تلاميذ الصف الثالث الإعدادي، وتوصلت در استة (أسـامة

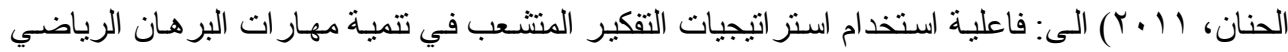

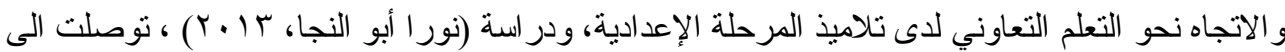

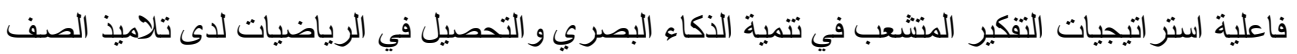

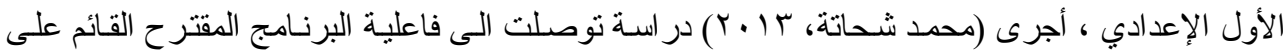

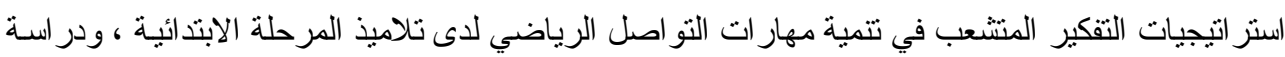

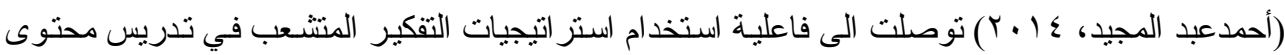

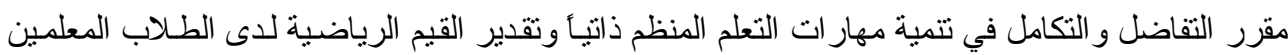

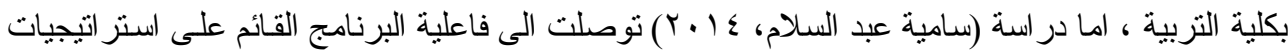

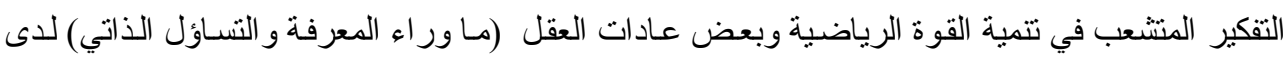
تلاميذ المرحلة الإعدادية ، ودر اسة (أسماء السروجي ، 17 ب ب ) تمثلت أهم نتائجها في فاعلية البرنامج القائم

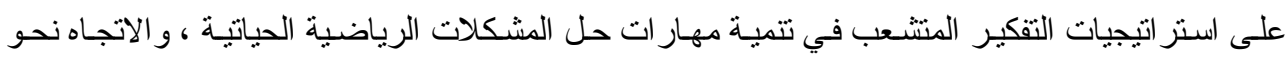
الرياضيات لاى تلاميذ المرحلة الإعدادية.

ومن خلال ما تم عرضه من الدر اسات السابقة يتضح أهمية استر اتيجيات التفكير المتتشب في تنمينة

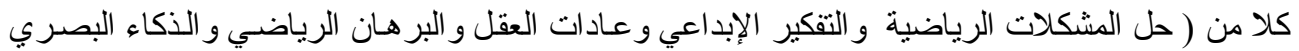

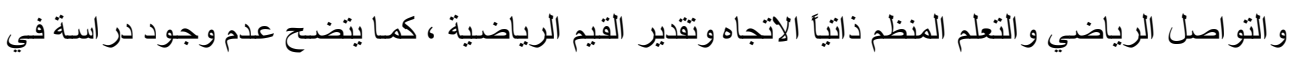

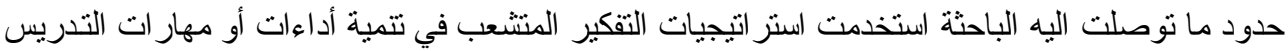

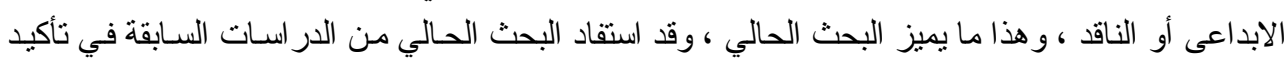

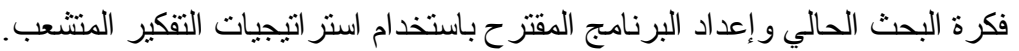

\section{مهارات وأداءات التدريس الإبلداعى والناقد}

هي تلك المهار ات التشريسية و الأداءات التي يقوم بها المعلم أو الطالب المعلم بشعبة الرياضيات من

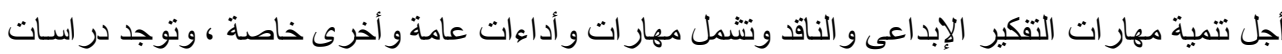

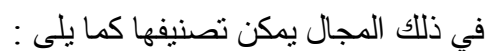
أولاً : الدر سات التي تتاولت أداءات نتمية التفكير عامة من خلال الرياضيات ( ايمان الريس، ب ا ب ) ، ولم توجد در اسة واحدة نمت أداءات التفكير الناقد. ثانياً : الدر اسات التي تتاولت تتمية دهار ات التدريس الإبداعى. 


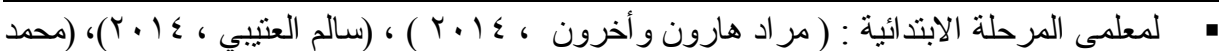

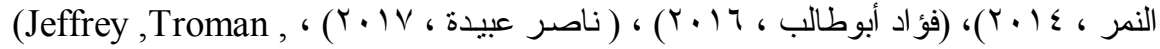

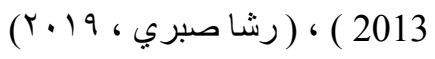

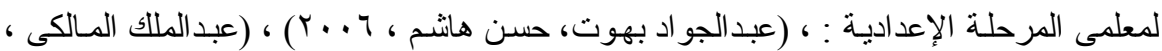

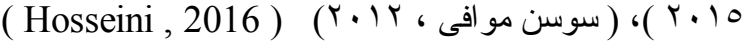

ثالثاً: در سات تتاولت تتمية مهار ات التدريس الإبداعى للطلاب المعلمين (رضـا مسعد، (1991) ) ، (سمير

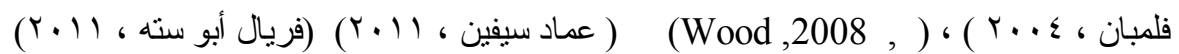

$$
\text { وفيما يلى عرض موجز لهذه الدراسات : }
$$

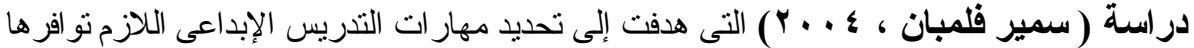

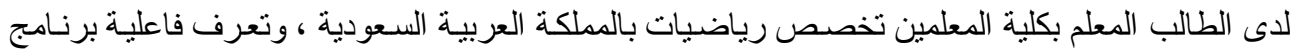

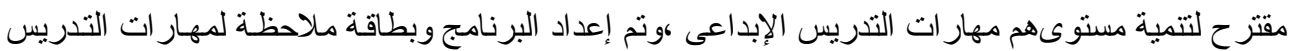

الإبداعى ، وتوصلت النتائج إلى فاعلية البرنامج فى تتمية مهار ات التنريس الإبداعى لدى عينة الدر اسة الإسل .

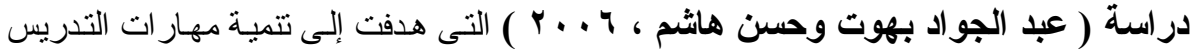
الإبداعى لاى معلمى الرياضيات بالمرحلة الإعدادية من خلال موديول قائم على الأسئلة التباعدية ، وتمثلت

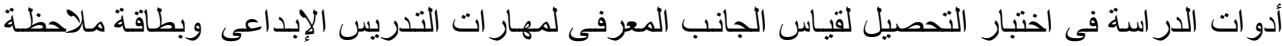
لقياس الجانب الأدائى لمهار ات التدريس الإبداعى إضافةً إلى الموديول التعليمى القائم على الأسئلة التباعدية ،

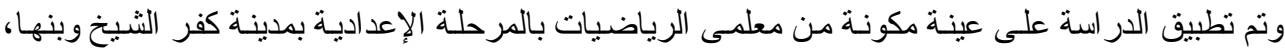

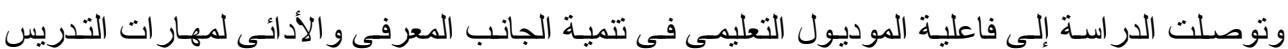
الإبداعى، وجود ارتباط موجب دال إحصائياً بين التحصيل للجانب المعرفى و الأداء التذريسى الإبداعى .

دراسة (Schacter, Meng,Zifkin, 2006) هدفت الى در ساة العلاقة بين ممارسات عينة من معلمى رياضيات المرحلة الابتدائية (للصفوف من الثالث حتى السـادس ) بمدارس الطـلاب الافريقيين

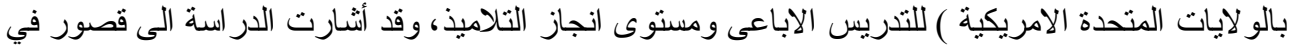

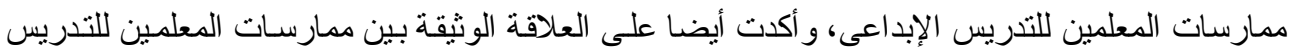
الإبداعى ومستوى انجاز التلاميذ.

در اسـة وود وأشفاليا (Wood \& Asfield,2008) التى هدفت إلى توضيح الأسـاليب

و الطرق النى تسهر من خلالها السبورة البيضـاء التفاعلية (IWB) فى دعم وتعزيز ممارسـات التدريس الإبداعى فى القر اءة و الكتابة و الحساب وكذللك تحديد تصور ات الطلاب المعلمين نحو استخدامها في دعم عمليتى التعليم و التعلم وتوصلت النتائج إلى أن تقنية السبورة البيضاء التفاعلية تدعم التدريس الإبداعى. 


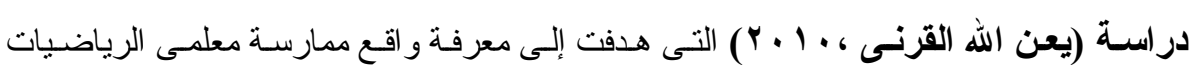

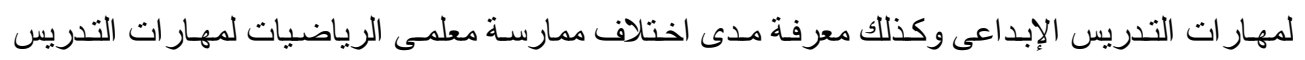

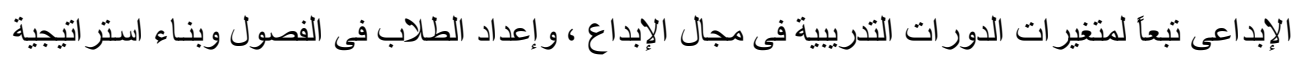

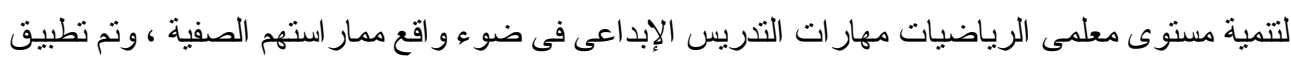

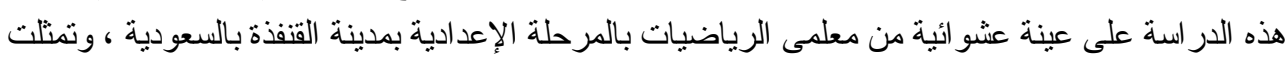

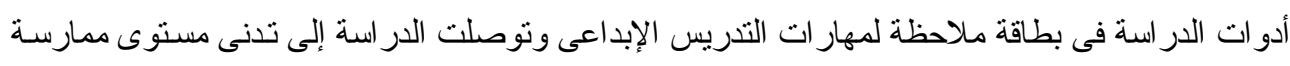

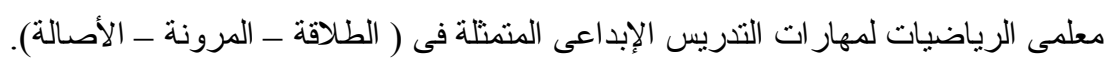

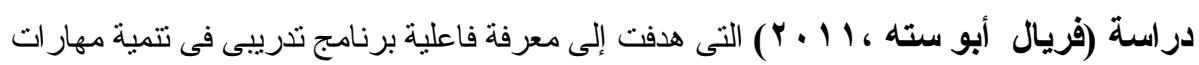

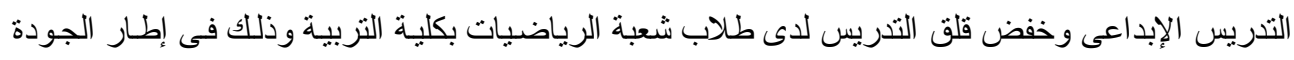

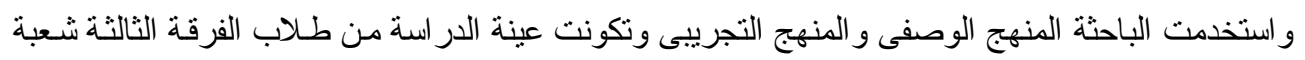

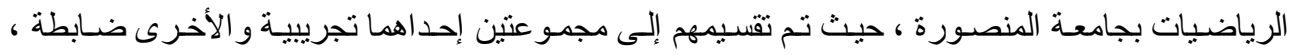

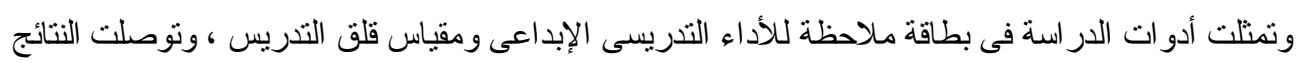
إلى فاعلية البرنامج التندريبى فى تثمية مهار ات التندريس الإبداعي.

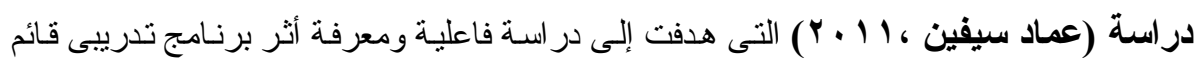

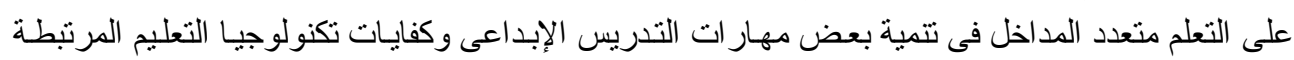

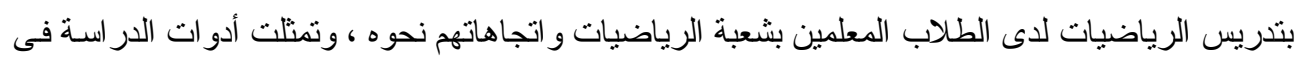

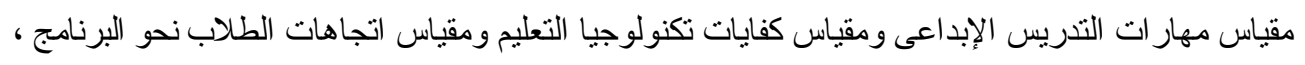

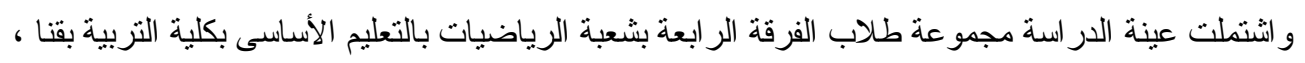

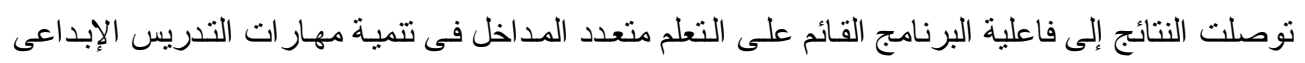

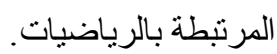

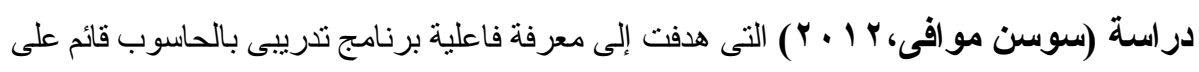

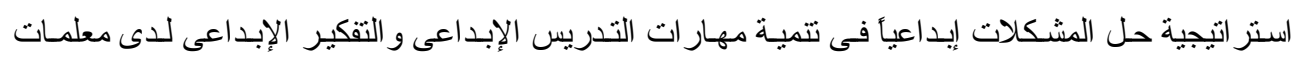

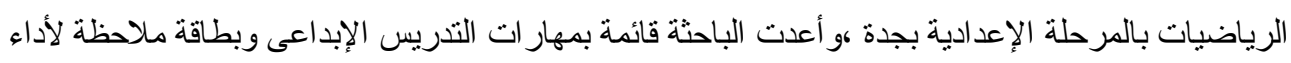

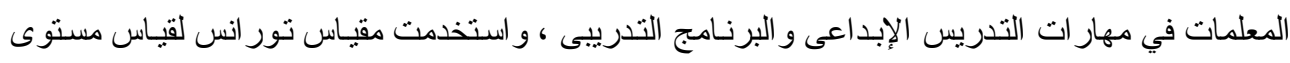

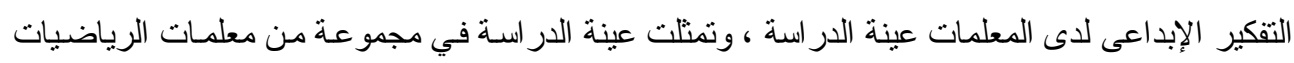

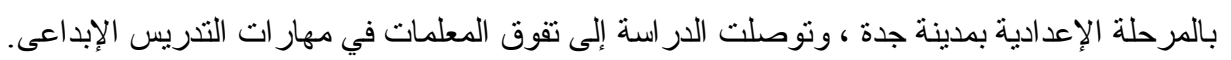

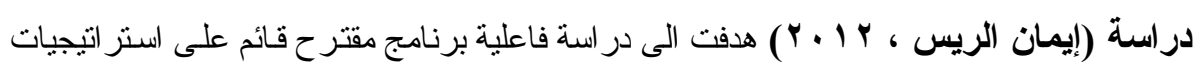

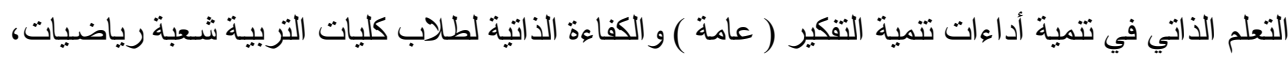




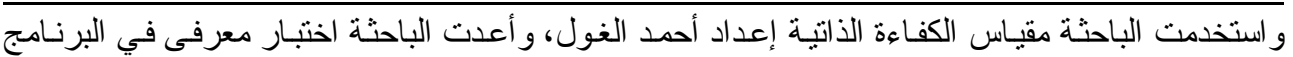

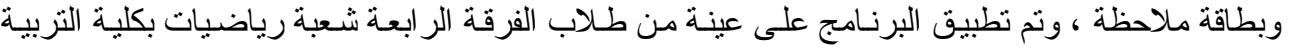

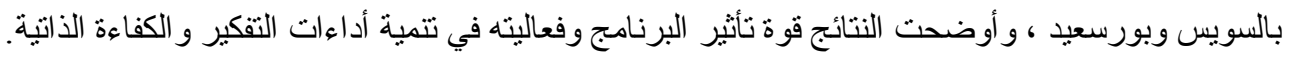
دراسـة ( Jeffrey ,Troman, 2013 ) هدفت الـى تقيهم ممارسـات معلمى الرياضيات

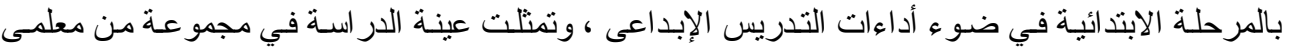

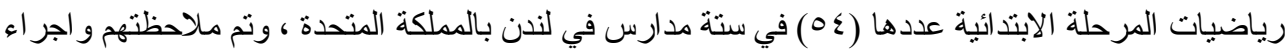
مقابلات معهم ، و أكدت النتائج الى تدنى مستويات المعلمين فى ممارسات التدريس الإندات فيداعى.

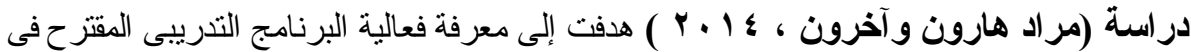

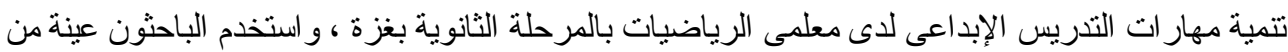

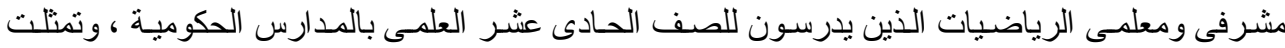

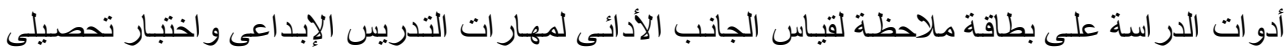
لقياس الجانب المعرفى لمهار ات التنريس الإبداعى ، وتوصلت الدر اسة إلى ضعف تو افر مهار ات التهات التدريس الإبداعى المرتبطة بمر احل التدريس (التخطيط - التتفيذ - التقويم ) لاعى معلمى الرياضيات (عينة الدر اسـة)

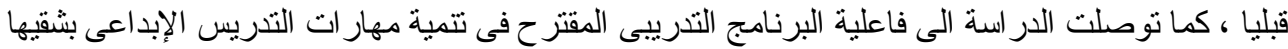

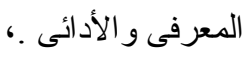

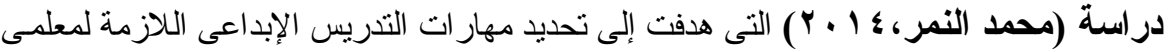
الرياضيات بالمرحلة الابتدائية بالمملكة العربية السعودية ومعرفة مدى امتلاكهم لهذه المهار ات ، وتكونت

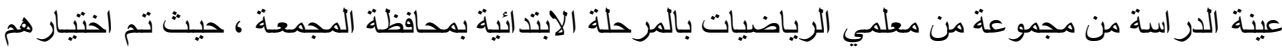
بطريقة قصدية ، وذلك لتطبيق بطاقة الملاحظة التي شلت مهار ات التنريس (الطلاقة ـ المرونة ـ الأصالة

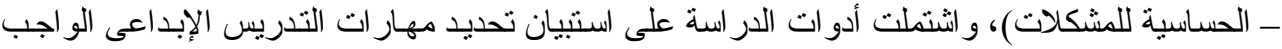

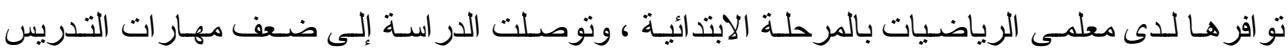

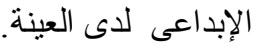

در اسة (عبد الملك المالكى، 1 ب) التى هدفت إلى التعرف على مدى ممارسة معلمى الرياضيات بالمرحلة المتوسطة بجدة بالمملكة العربية السعودية لمهار ات التدريس الإبداعى، و أعد الباحث بطاقة ملاحظة

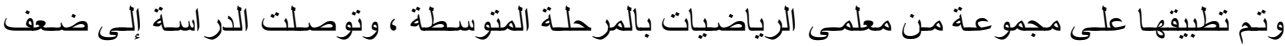
ممارسة معلمى الرياضيات لمهار ات التدريس الإبداعى .

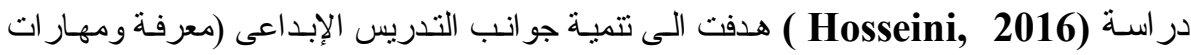
و اتجاهات) لمعلمى المرحلة الابتدائية من خلال برنامج تدريبي يتضمن مفهوم ومبادئ التدريس الإبداعى لإئ 
و استر اتيجيات التدريس الإبداعى للى عينة من معلمى رياضيات المرحلة الابندائية و أعد الباحث بطاقة

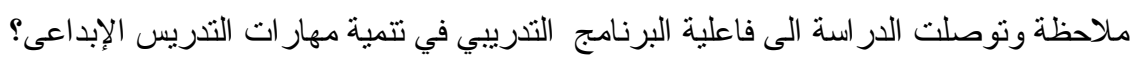
دراسة (فؤاد أبو طالب، 17 ـ ب ) التى هدفت إلى تقويم أداء معلىى الرياضيات بالمرحلة الابندائية

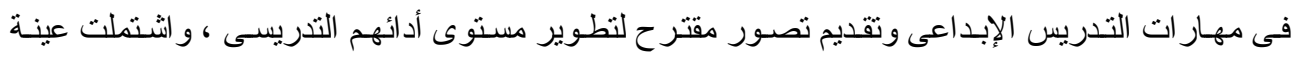

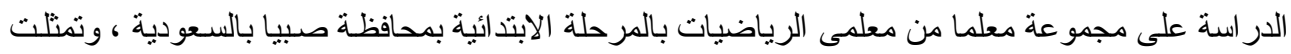

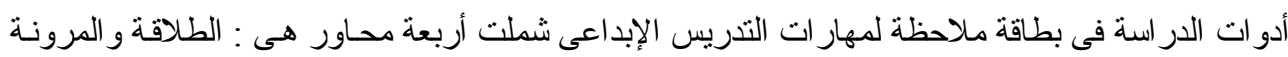

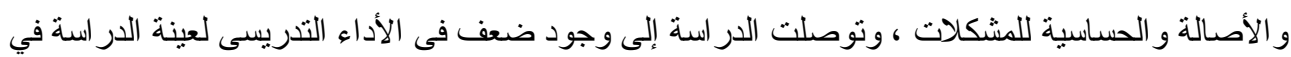

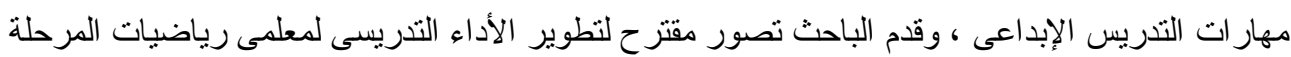

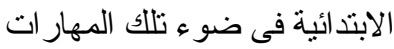

در اسة (رشا صبري ، 9 ( ب) هدفت الى در اسة أثر برنامج مقتر ح في تعلم حب الرياضيات بالاستعانة بتطبيقات الحوسبة السحابية وقياس أثره على تتمية مهار ات التدريس الإبداعى و الاتجاه نحو التعلم

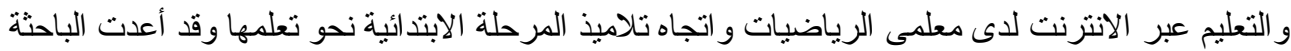

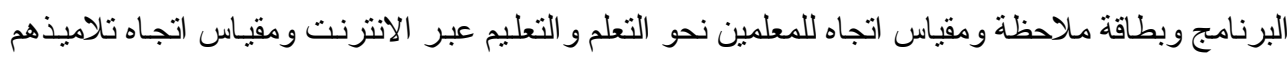

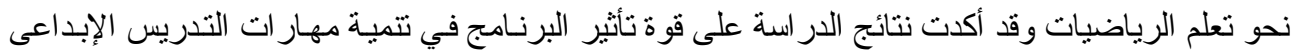
وتتمية اتجاه المعلمين وتلاميذهم .

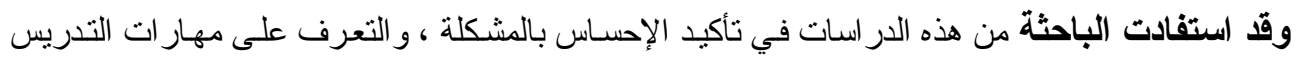
الإبداعى ، وبعض أداءات تدريسه ، و إعداد البرنامج ، كما تم الاستفادة من هذه الدر استات في إعداد الإد الاختبار

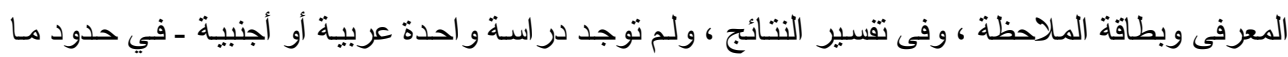
اطلعت عليه الباحثة ـ تتاولت أداءات تتمية مهار ات التفكير الناقد فقط ، أو أداءات تتمية التفكير مهار ات الناقد

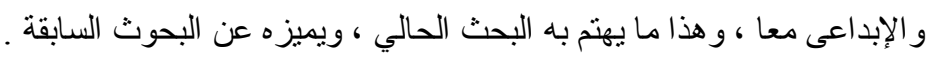

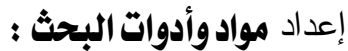

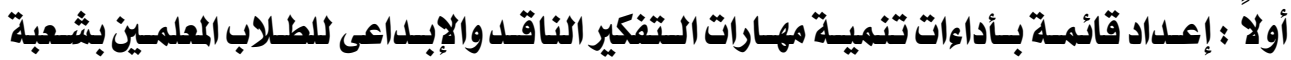

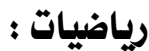

تم إعداد القائمة من خلال الدر اسة النظرية و التحليلية للأدبيات و الدر اسات السابقة في الدجال وطبيعة

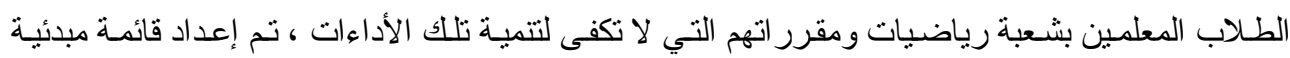

$$
\text { تضمنت ثلاثة أبعاد : }
$$

$$
\begin{aligned}
& \text { 1 - ـ أداءات تتمية مهار ات التفكير الناقد. } \\
& \text { r- أداءات تتمية مهار ات التقكير الإبداعى. }
\end{aligned}
$$


r- بيئة تتمية مهار ات التفكير الناقد و الإبداعى.

وقد تم عرض القائمـة على مجموعـة من المحكمين (') في مجال المنـاهج وطرق تعليم الرياضيات

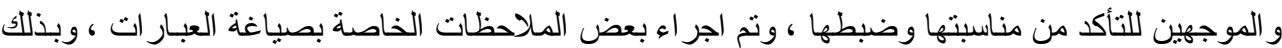

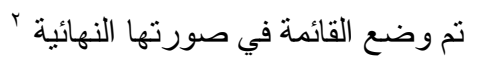

ثانياً : إعداد بطاقة الملاحظة لأداءات التدريس المنمية لمهارات التفكير الناقد والإبـلـاعى من خلال

\section{تعليم الرياضيات}

تم إعلداد البطاقة في ضو ء قائمة الأداءات السابقة كما يلى :

تحديـد الهـدف مـن البطاقة : ملاحظة وقيـاس مستوى الطـلاب المعلمين بثـعبة الرياضيات في أداءات

التدريس المنمية للتفكير الناقد والإبداعى مئى

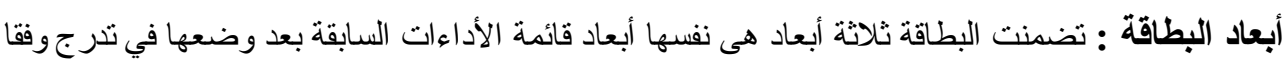

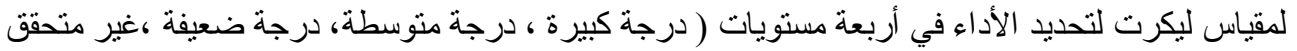

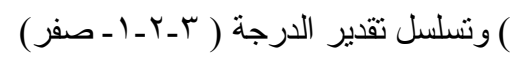

ضبط البطاقة تم عرض البطاقة على مجمو عة من الحكمين للتأكد من صدقها ومناسبتها وسلامنها اللغوية ،

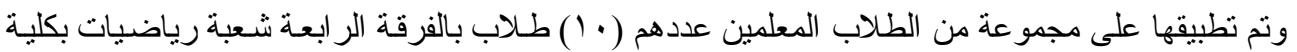

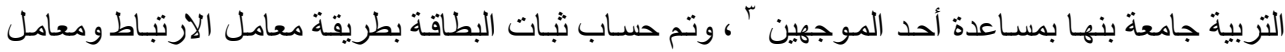

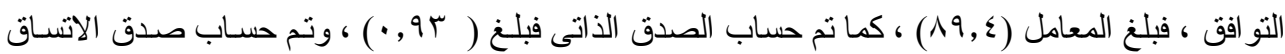

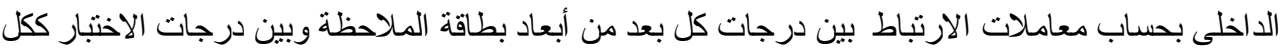

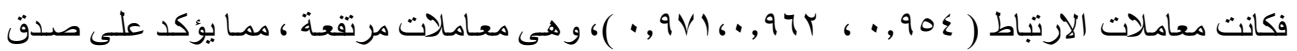

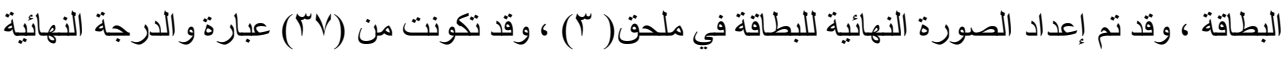




\section{تم إعداد البرنامج المقتزح وقتا للخطوات التالية :}

تحديد أسس بناء البرنامج : من خلال الدر اسة النظرية لطبيعة ومهار ات التفكير الناقد و الإبداعى ، وكيفية

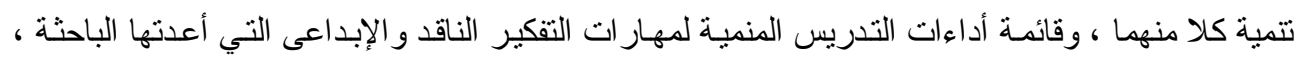

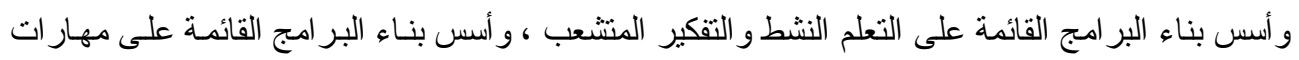

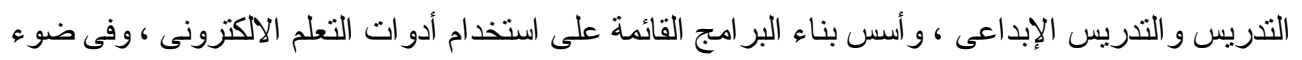

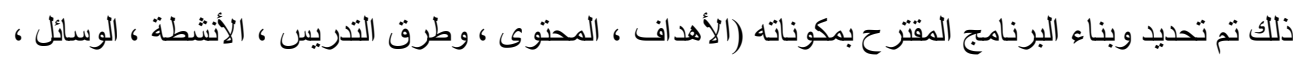

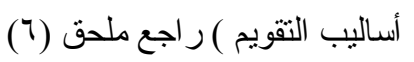

تحليل الهلدف العام للبرنـامج : يهدف البرنـامج بصفة عامـة الى تتميـة مسنوى الطلاب المعلمين بشعبة

$$
\text { رياضيات أداءات التنريس المنمية لمهار ات التفكير الناقد و الإبداعى. }
$$

تحليد الأهداف الإجرائية للبرنامج : تتشل أهداف كل لقاء وكل ورشة ، وتم تجميعها في ملحق(V)، وقد

$$
\text { محتوى البرنامج : تضيها الوضوح ، إمكانبة النحقيق و القياس و الملاحظة. }
$$

ـ الوحدة الأولى : تمهيد ومر اجعة ما تم در استه في عن مهار ات التدريس ـ الوحدة الثانية : أداءات وبيئة تتمية مهار ات التفكير الناقد

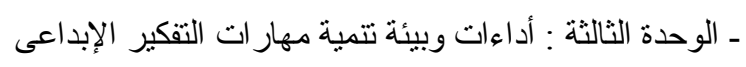

ـ الوحدة الر ابعة : نموذج تدريسي مقتر ح لنتمية مهار ات التفكير الناقد و الإبداعى (يثمل مهار ات و أداءات

$$
\text { التدريس العامة و الأداءات المنمية لدهار ات التفكير الناقد و الإبداعى ) }
$$

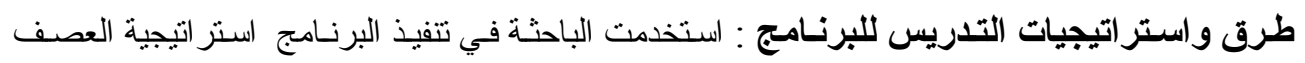

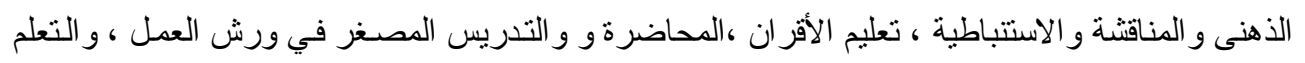

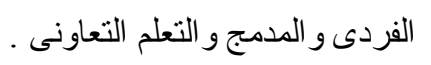


يعتمد البرنامج في تتفيذه على استخد ام وسائل التعلم التقليدية منل السبورة البيضاءو الاقالام و الأدوات التاتي

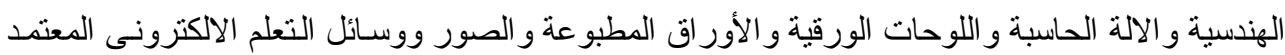

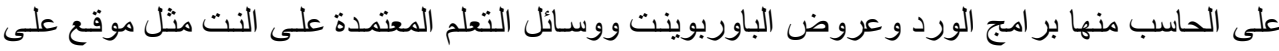

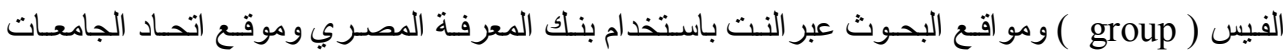
المصـرية ومو اقـع تعليم الرياضيات في اليوتيوب ومحركـات البحوث مثنل Google و ومجلـة تربويـات الرياضيات ومؤتمر اتها و اليوتيوب و استخدام الو انس اب و الايميل و التليجر ام لنقل ونقد وتبادل فيديو هات التنريس في ورشة العمل أو في حصة الرياضيات وبات بالتربية العملى.

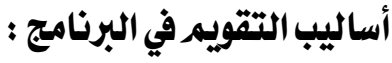

تقويم قبلى وبعدى من خلال تطبيق أداتا البحث قبليا وبعديا ، وتقويم مستمر من خـلال الأسئلة التي

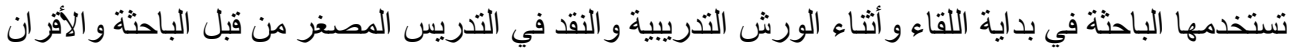

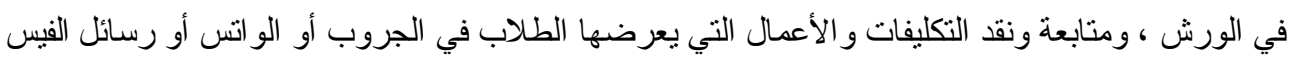

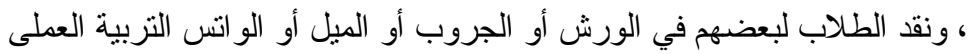

عرض البرنامج على مجموعة من المحكميز للتأكد من مناسبته لتحقيق أهدافه ولطبيعة العينة و التأكد من

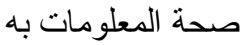

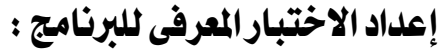

الهلدف العام للاختبار : تحديد مستوي الطلاب المعلمين عينة البحث في الجانب المعرفى للبرنامج

و أداءات تتمية مهار ات التفكير الناقد قبل وبعد تطبيق البرنامج ، مما يفيد في قياس فاعلية البرنامج ، وتحديد مستوى الطلاب في الجو انب المعرفية للأداءات التدريسية المنمية للتفكير الناقد و الإبداعى.

الأهداف السلوكية : للاختبار نم وضع أهداف سلوكية إجر ائية منبققة من الأهداف قصيرة المدى

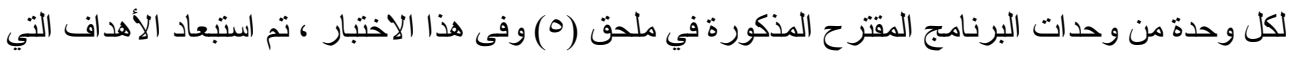

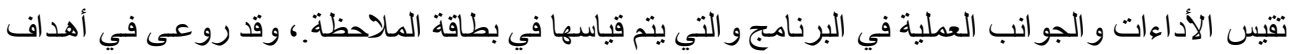

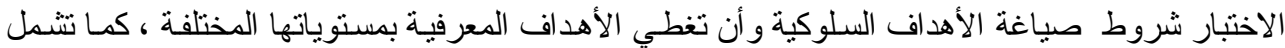

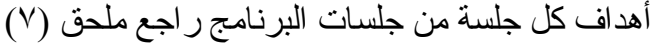


إعداد مفردات الاختبار نم إعداد مفردة لقياس كل هدف و المفردات من نوع الأسئلة الموضوعية

تحديدا ( أسئلة الاختيار من متعدد ).

\section{إعداد جدول المواصفات للاختبار المعرفى للبرنامج}

تم وضع مفردة لقياس كل هدف سلوكى اجر ائى في ملدق (V) ) و وذلك بعد تصنيفها الى المستويات

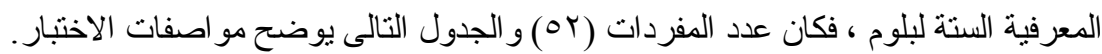
جدول ( 1 ) مواصفات الاختبار المعرفى للبرنامج

\begin{tabular}{|c|c|c|c|c|c|c|c|}
\hline المجموع & تقويم & تركيب & تحليل & تطبيق & فهم & تذكر & الأهداف \\
\hline & $\begin{array}{l}\text { 6ro } \\
\leq 0,01 \\
\text { or. }\end{array}$ & 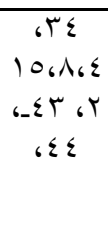 & 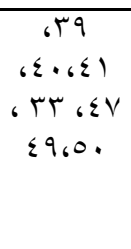 & 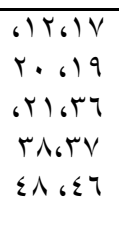 & 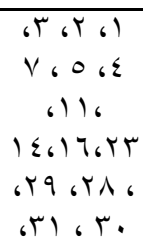 & 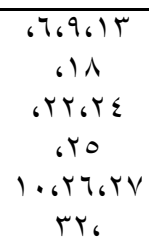 & \\
\hline Or & $\varepsilon$ & 7 & V & 1. & $1 \varepsilon$ & 11 & المجموع \\
\hline
\end{tabular}

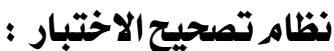

حيث أن الاختبار من نوع الاختيار من متعدد ، لذللك نم اتباع نظام موحد للتصحيح وهو : (صفر اذا

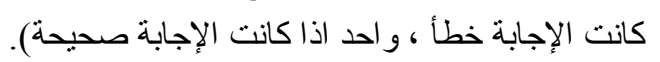
صياغة تعليمات الاختبار : نم صياغة التعليمات بصورة واضحة ودقيقة للطلاب. صلدق المحكميسن تم عرض الاختبار على مجموعة من المحكمين من تخصص المنـاهج وطرق التنديس و أساتذة المناهج وتعليم الرياضيات بكليات التربية (ملحق ( ) للتأكد من صدق الاختبار ، وتم اجر اء بعض الملاحظات الخاصة بالصياغة اللغوية لبعض المياضات المفردات. التجربة الاستطلاعية للاختبار نم اختبار عينة من الطلاب المعلمين بشعبة رياضيات الفرقة الر ابعة عام 11 • ب عددهم ( • (ץ) طالبا وطالبة من غير مجموعة البحث الأساسية. ثبات الاختبار تم حساب ثبات الاختبار بطريقة ألفا كرونباخ فبلغ ( ^, د ) ، وتم حساب الصدق الذاتي 
إعداد نموذج الإجابة للاختبار تم إعداد نموذج إجابة للاختبار ر اجع ملحق ( )

اختيار عينة البحث : نم اختبار مجموعة من الطلاب المعلمين بالفرقة الر ابعة شعبة رياضيات عام بكلية

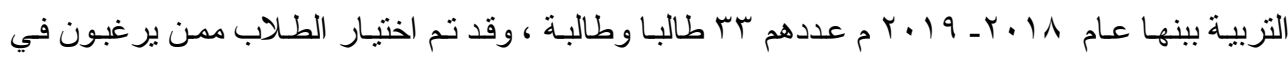

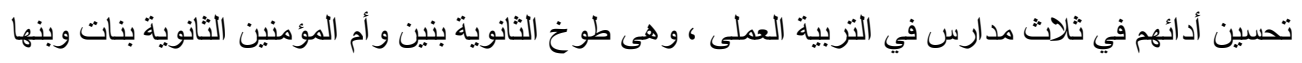
الثنانوية بنين.

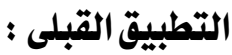

تم تطبيق الاختبار المعرفى للبرنامج وبطاقة الملاحظة على الطلاب قبليا في بدايـة الفصل الدر اسى الإسى

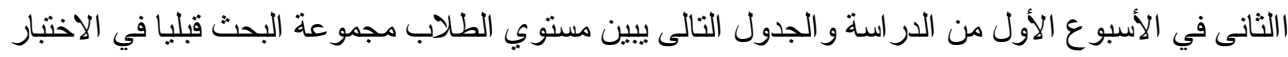
المعرفى للبرنامج وبطاقة الملاحظة. 


\section{جدول ( † ) يبين مستوي الطلاب مجموعة البحث قبلياً}

في الاختبار المعرفى للبرنامج وبطاقة الملاحظة

\begin{tabular}{|c|c|c|}
\hline المتوسط & الدرجة الكلية & الأداة \\
\hline $1 \varepsilon, \wedge Y$ & Or & الاختبار المعرفى ككل \\
\hline rq,7V & 111 & بطاقة الملاحظة ككل \\
\hline 9,00 & r. & تلمية التفكير الناقد الأول ملاحظـــة أداءات \\
\hline $19, Y \varepsilon$ & $0 \leqslant$ & تنمية التفكير الإبـداعى ملاحظـــة أداءات \\
\hline $1 \cdot, \wedge \Lambda$ & TV & بيئة التعلم الثالـث ملاحظــة أداءات \\
\hline
\end{tabular}

ومن الجدول يتضح تدنى مستوي الطلاب المعلمين في الاختبار المعرفى وبطاقة الملاحظة ككل وفى

كل بعد منها مما يؤكد ضعف على ضعف مستوى الطلاب المعلمين في الجانب المعرفى و الأدائسى البرنامح

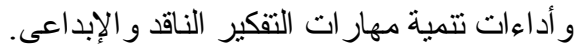

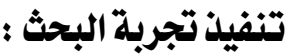

بعد تطبيق الأدو ات قبليا ، تم استخدام أدو ات التعلم المعتدة على النت منها الميل و الفيس و الو اتس

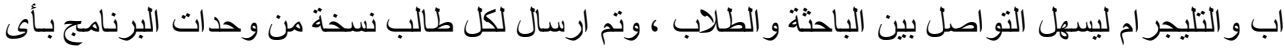

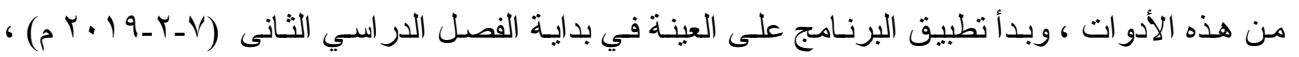

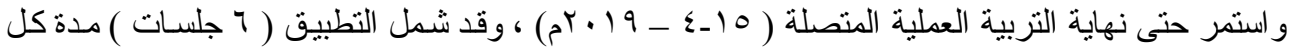

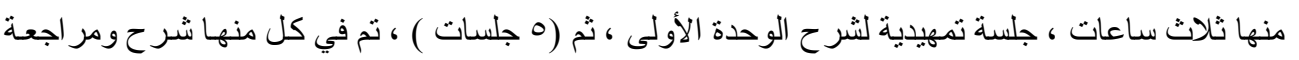

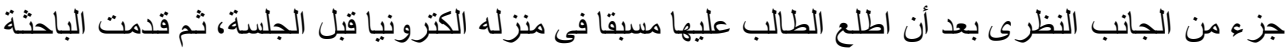

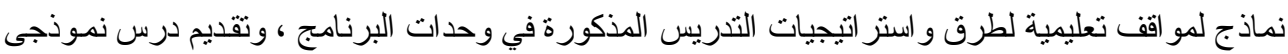

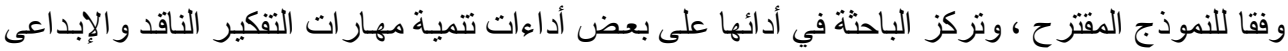
الو اردة في قائمة الأداءات السابقة بالبحث، ومنها التهيئة و البيئة المناسبة و التفاعل و استخدام وسائل و وأنشطة

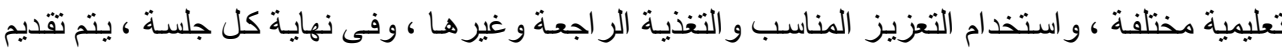

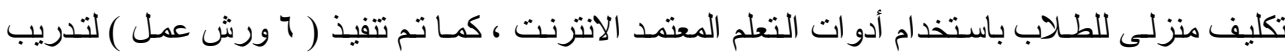

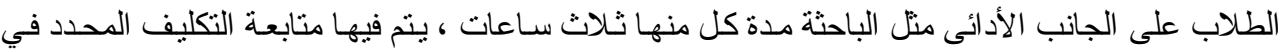
الجلسة السابقة ، و أيضا في نهاية كل ورشة يقدم للطلاب تكليف منزلى يقوم الطالب بـه بـالاطلاع ، وتجميع

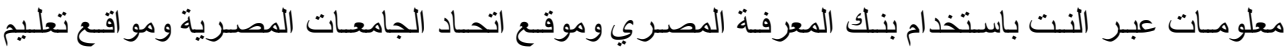
الرياضيات في اليوتيوب ومحركات البحوث متل Google ومجلة تربويات الرياضيات ومؤتمر اتها أومكتبة 
الكلية ، وقد أعد الطلاب مو اقف تعليمية ودروس، وتم ارسال التكليفات للباحثة باستخدام و الفيس و التليجر ام

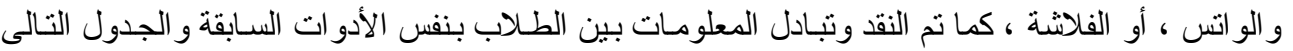
يوضح خطة تتفيذ البرنامج.

جدول ( r ) خطة تنفيذ البرنامج المقترح

\begin{tabular}{|c|c|c|c|}
\hline الزمن & ما بقدم فيها & الجلسة & r \\
\hline$r$ & 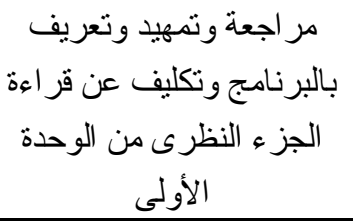 & تمهيد وتكليف ( ) & الوحدة الأولى \\
\hline r & الجز ء نظرى وشعة التكليف السابق النماذج & 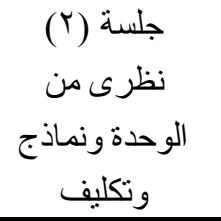 & \multirow[t]{4}{*}{ 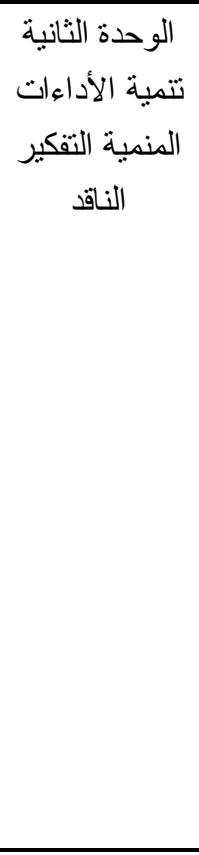 } \\
\hline r & 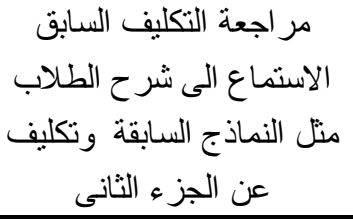 & 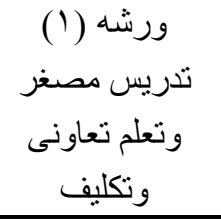 & \\
\hline r & 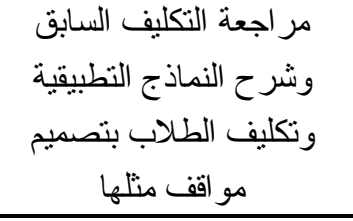 & جلسة (ب) تكملة & \\
\hline r & و متابعة التكليف السابق النى شرح الطلاب & تدريس مصغة (r) ونعل & \\
\hline \multicolumn{4}{|c|}{ 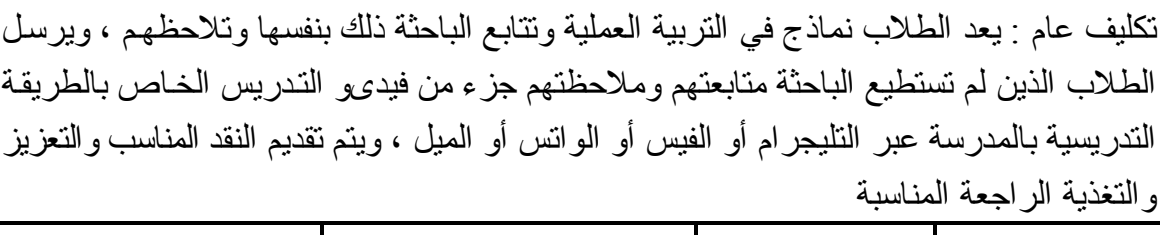 } \\
\hline$r$ & مثل جلسة ب ولكن في & جلسة (乏) & الوحدة الثالثة \\
\hline
\end{tabular}




\begin{tabular}{|c|c|c|c|}
\hline \multirow[t]{2}{*}{ الزمن } & ما يقدم فيها & الجلسة & م \\
\hline & الوحدة الثانية & 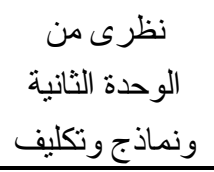 & \multirow[t]{3}{*}{ 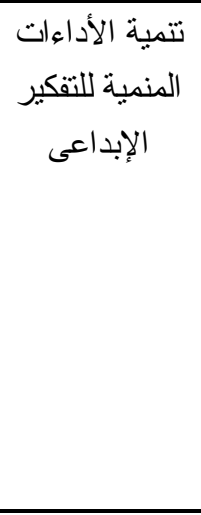 } \\
\hline r & منل ورشة ( الوحدة الثانية ولكن في & ورشة (r) & \\
\hline r & مثل جلسة ب ولكن في & 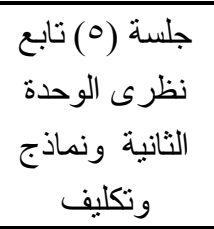 & \\
\hline$r$ & منل ورشة ب ولكن في & ورشة و ع ) & \\
\hline \multicolumn{4}{|c|}{ 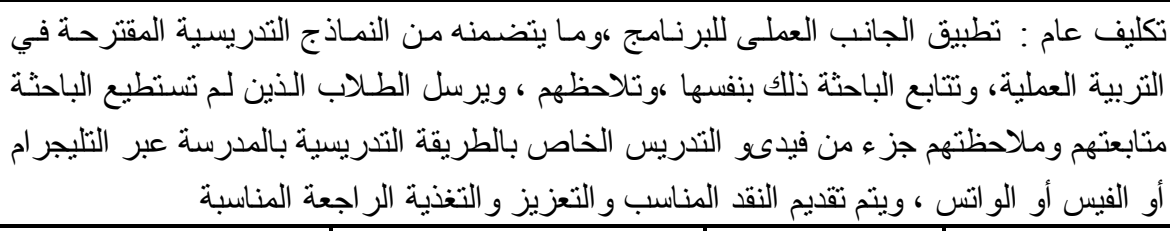 } \\
\hline$r$ & $\begin{array}{l}\text { المقيم وشر ح النموذج وشر ح درس تطبيقى } \\
\text { تقبر }\end{array}$ & جلسة (ך) & \multirow{2}{*}{ النموذج المقترح الر ابعة } \\
\hline$r$ & منل ورشة ب ولكن يقدم & ورشة (0) & \\
\hline r & منل ورشة ع ولكن على النموذج المقترح & ورشة (1) & \\
\hline \multicolumn{4}{|c|}{ 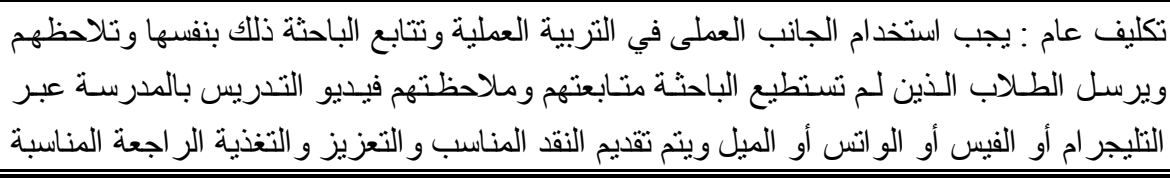 } \\
\hline
\end{tabular}




\begin{tabular}{|c|c|c|c|}
\hline الزمن & ما يقدم فيها & الجلسة & 5 \\
\hline هـ من دون ساعات التدريب في مدارس & & 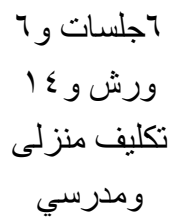 & الاجمالى \\
\hline
\end{tabular}

ويوضح ملحق (9) صور و نماذج لأعمال الطلاب، كما يمكن الاطلاع على نماذج ورقية لأعمال الطلاب في ورش العمل وتحضير ات التربية العملية ، ولفيديوهات الطلاب في التربيـة العملي أثناء تتفيذهم

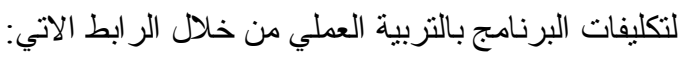
التطبيق البعدي تم تطبيق الاختبار المعرفى وبطاقة الملاحظة في نهايـة الفصل الدر اسي الثانى ، وذلك بملاحظة كل طالب مرنين و أخذ المتوسط.

\section{نتائج البحث وتفسيرها :}

للتحقق مـن صـة الفرض الأول والذى ينص على " يوجد فرق دال احصـائيا عند مستوى

(0 . , • ) بين منتوسطى درجات الطلاب المعلمين قبليا وبعديا في الاختبار المعرفى لأداءات التدريس المنمية للتفكير الناقد و الإبداعى " تم حساب قيمة ت ودلالة الفرق بين منتوسطى أداء الطلاب قبليا وبعديا في الاختبار المعرفى، و الجدول التالى يوضح قيمة ت ودلالة الفرق بين منوسطى درجات الطلاب مجموعة البحث قبليا وبعديا في الاختبار المعرفى. ولى لمعي. 
جدول ( ؛ ) يوضح قيمة ت ودلالة الفرق بين منوسطى درجات الطلاب مجموعة البحث قبلياً وبعدياً في الاختبار المعرفى لافئ

\begin{tabular}{|c|c|c|c|c|c|c|c|}
\hline مربع ايتا & مستوى الدلالة & قيمة ت & الالنحر افيارى & المتوسط & الارجهائية & دالحرية & التطبيق \\
\hline \multirow[t]{2}{*}{$\cdot, 97 r$} & \multirow[t]{2}{*}{$\cdot, \cdot 1$} & \multirow[t]{2}{*}{$r \wedge, \leqslant V_{-}$} & $v, r q$ & $\mid \varepsilon, Y \wedge$ & \multirow[t]{2}{*}{ Or } & \multirow[t]{2}{*}{ Tr } & القبلى \\
\hline & & & $\varepsilon, \varepsilon \Gamma$ & $\sum 1, \xi Y$ & & & البعدى \\
\hline
\end{tabular}

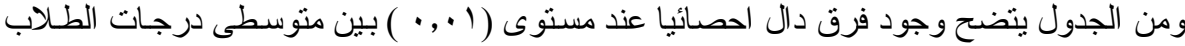

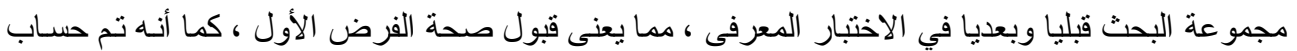
قوة التأتير باستخد ام مربع ايتا ، فوجد أن قيمة مربع ايتا (ب جو و • ).

ويمكن تفسير ذلك بأن البرنامج المقتر ح بتضمن في وحداته المعلومات التي تغطى الجانب المعرفى

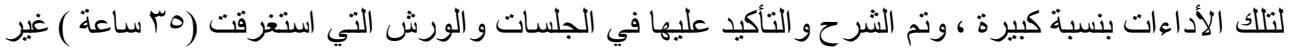
التكليفات المنزلية الالكترونية في التعليم الفردى و الجماعى، وتقديم التقويم المستمر للطـلاب في الجلسـات

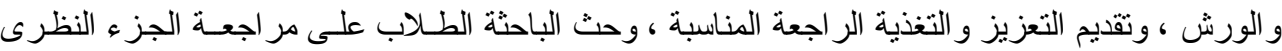

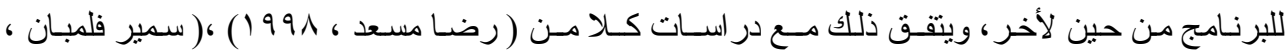

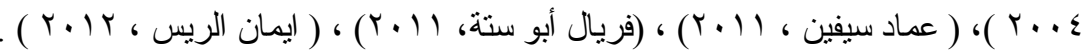
وللتحقق مـن صحة الفرض الثـانى والذى ينص على " يوجد فرق دال احصائبا بين متوسطى

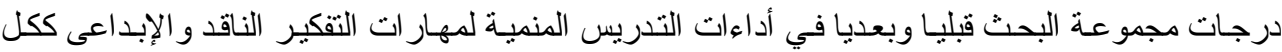

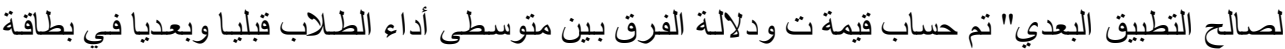

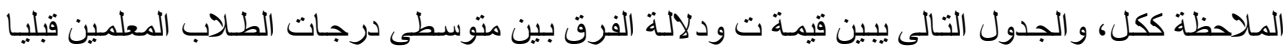
وبعديا في بطاقة الملاحظة 
جدول ( • ) يوضح قيمة ت ودلالة الفرق بين متوسطى درجات الطلاب المعلمين

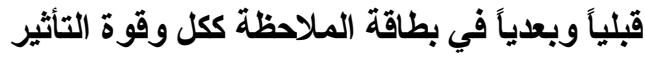

\begin{tabular}{|c|c|c|c|c|c|c|c|}
\hline مربع ايتا & الدسلة & قيمة ت & المعيارى اف & المتوسط & النارجة & درجاتة & التطبيق \\
\hline \multirow[t]{2}{*}{., 9010} & $\cdot,+, 1$ & \multirow[t]{2}{*}{$r v, 1 q_{-}$} & $I \Psi, V V$ & $r q, 7 v$ & \multirow[t]{2}{*}{111} & \multirow[t]{2}{*}{ Tr } & القبلى \\
\hline & & & $9, Y 7$ & $\overline{\lambda \varepsilon, Y V}$ & & & البعدى \\
\hline
\end{tabular}

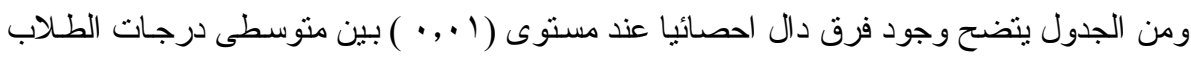

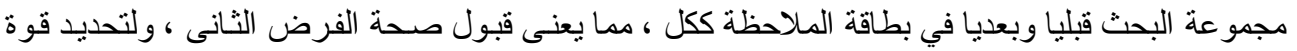

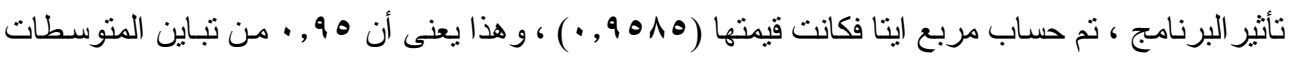
و الدرجات بين التطيقين القبلى و البعدى يرجع الى البرنامج.

ويمكن تفسير ذلك بأن البرنامج يتضمن فى جز أيه المعرفى و العملى مـا يسـاعد الطـلاب على اتقان

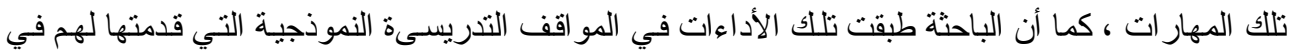
جلسات البرنامج ، وتابعت تتفيذ واستخدام الطلاب المعلمين في ورش العمل ، ونطبيقات الطلاب وشرحهر

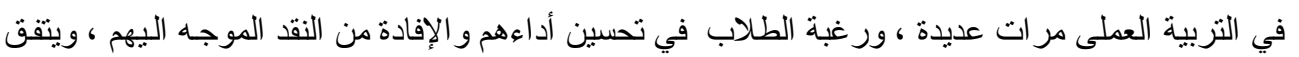

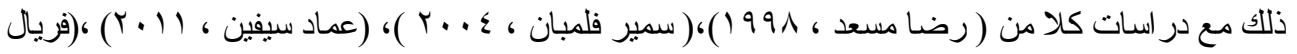

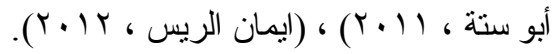

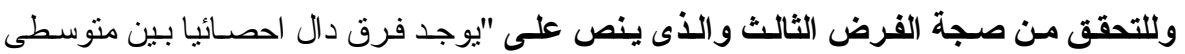

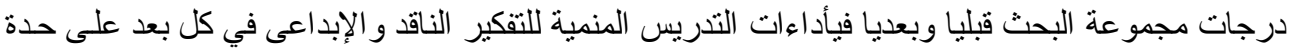

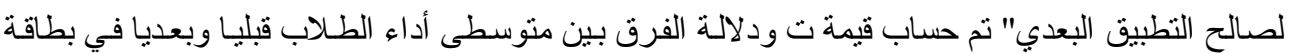
الملاحظة ، و الجدول النالى بيين قيمة ت ودلالة الفرق بين منوسطى درجات الطلاب المعلمين قبليا وبعديا في كل بعد من أبعاد بطاقة الملاحظة. 
جدول ( 7 ) يوضح قيمة ت ودلالة الفرق بين متوسطى درجات الطلاب المعلمين قبليا وبعيا في كل بعد من أبعاد بطاقة الملاحظة

\begin{tabular}{|c|c|c|c|c|c|c|c|c|}
\hline مربع & الدلالة & قيمة ت & الانحر اف & المتوسط & الأنهائية & درجات & التطبيق & البعد \\
\hline \multirow[t]{2}{*}{$\cdot, 9 \leq 1$} & \multirow[t]{2}{*}{$\cdot, \cdot 1$} & \multirow[t]{2}{*}{$r \varepsilon, 1 T_{-}$} & $\varepsilon, \cdot 9$ & 9,00 & \multirow[t]{2}{*}{$r}$. & \multirow[t]{2}{*}{ rT } & القبلى & الأول \\
\hline & & & T,TV & Y1,9E & & & البعدى & \\
\hline \multirow[t]{2}{*}{$\cdot, 9 \leq 9$} & \multirow[t]{2}{*}{$\cdot, \cdot 1$} & \multirow[t]{2}{*}{$r \leq, \Sigma \Lambda_{-}$} & $7, \wedge 7$ & $19, r \leq$ & \multirow[b]{2}{*}{$0 \leqslant$} & \multirow[b]{2}{*}{ Tr } & القبلى & الثانى \\
\hline & & & $\varepsilon, \wedge r$ & $\varepsilon \cdot, 9 \varepsilon$ & & & البعدى & \\
\hline \multirow[t]{2}{*}{$\cdot, 9 Y Y$} & \multirow[t]{2}{*}{$\cdot, \cdot 1$} & \multirow[t]{2}{*}{$19, \leqslant 0_{-}$} & r,oo & $1 \cdot, \wedge \wedge$ & \multirow[t]{2}{*}{ rV } & \multirow[t]{2}{*}{ Tr } & القبلى & \multirow[t]{2}{*}{ الثالث } \\
\hline & & & $r, \leqslant 0$ & $r), \varepsilon r$ & & & لبعدى & \\
\hline
\end{tabular}

ومن الجدول يتضح وجود فرق دال احصائيا عند مستوى ( ا ., · ) بين منوسطى درجات الطلاب

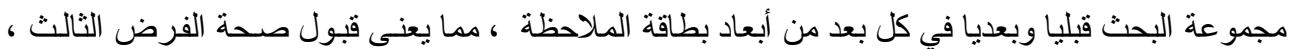

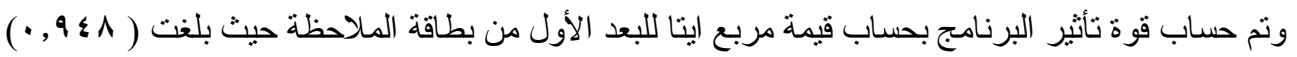

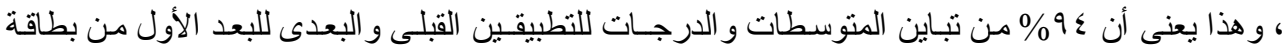

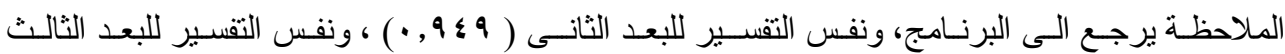

$$
\cdot(\cdot, 9 r \mathrm{r})
$$

ويمكن تفسير ذلك بأن البرنامج المقتر ح تضمن مو اقف ودروس نموذجية تقدمها الباحثة للطـلاب

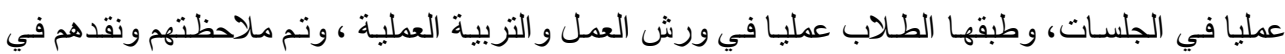
الورش و التربية العملية أو بمتابعة فيديو هات الطلاب فى المدارس ، وزيادة تحمس الطلاب لتحسين أداءهم و الإفادة من النقد الموجه اليهم.

\section{تعليـق عـام :}

ومن نتائج الفروض السابقة ، و التحقق من صحتها بحساب قيمة ت ودلالة الفروق بين متوسطات

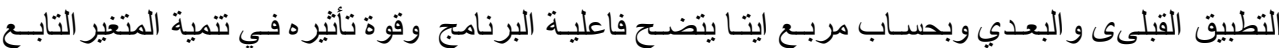

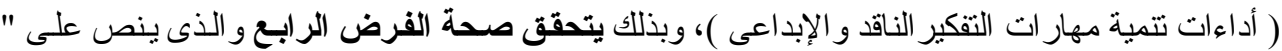

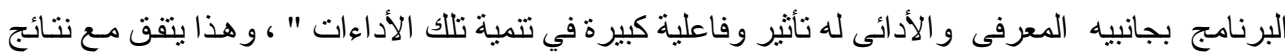

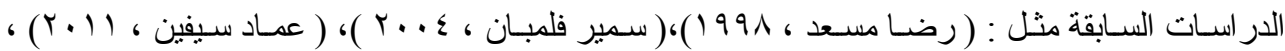




\section{في ضوي تجربة البحث ونتائجه توصى الباحثة بما يلى :}

ــ ـ الإفـادة مـن البرنــامج المقترح و أدو ات البحـث في تطـوير بـر امج إعـداد الطـلاب المعلمـين بثـعبة

$$
\text { الرياضيات. }
$$

r- الإفادة من قائمة اداءات تتمية التفكير الناقد و الإبداعى في تطوير بر امج إعداد الطلاب المعلمين بشعبة

$$
\text { الرياضيات. }
$$

r- الإفادة من البرنامج في تطوير مقررات طرق التدريس.

ع - الإفـادة مـن بطاقـة الملاحظة لأداءات تتميـة مهـار ات التفكير الناقد و الإبـداعى في ثقييم وتحسين أداء

الطلاب المعلمين بشعبة الرياضيات في التربية العملية.

ــ الإفادة من بطاقة الملاحظة فى تقييم معلمي الرياضيات ، و الإفـادة من قائمسة الأداءات و البرنـامج في تطويربر امج تدريب المعلمين بشعبة رياضيات.

المقترحســات :

\section{في ضوي نتائج البحث تقترح الباحثة بما يلى :}

ا - إعداد بر امج مفترحة أخري لتتمية تلك الأداءات للطلاب المعلمين r - إعداد بر امج مقترحة أخري لمعلمى الرياضيات لتتمية تلك الأداءات זـ إعداد بر امج مقترحة أخري لنتمية أداءات الطلاب المعلمين بشعبة رياضيات لتتميـة أنمـاط أخرى من التفكير.

ع ـ إعداد بر امج مقترحة أخري لنتمية أداءات المعلمين بشعبة رياضيات لتتمية لأنماط أخرى من التفكير. 


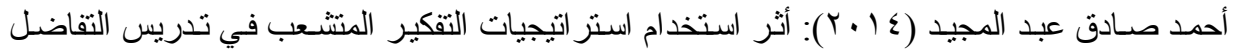

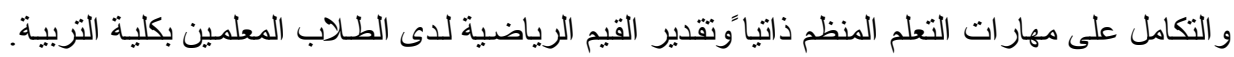

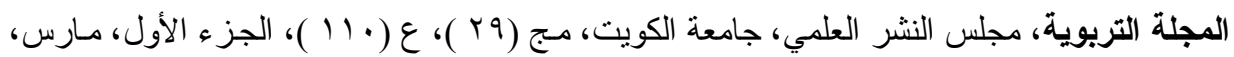

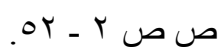

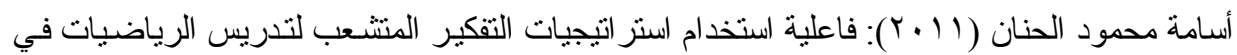

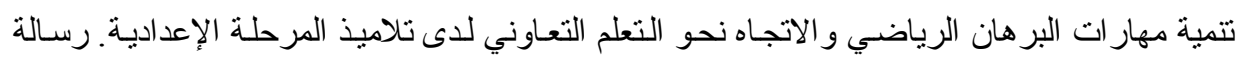
ماجستير ، كلية التزبية، جامعة أسيوط.

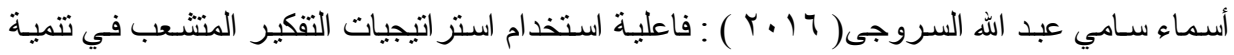

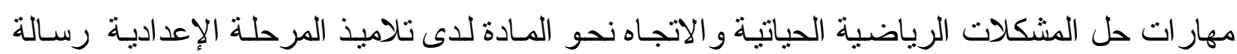

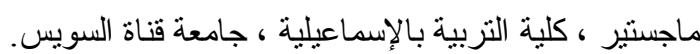

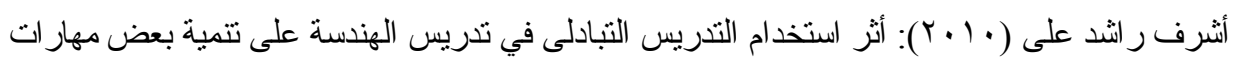

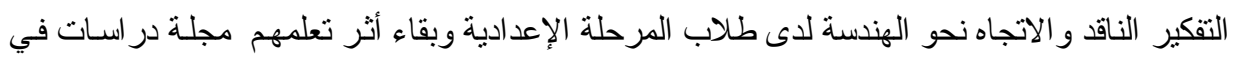

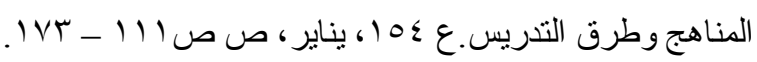

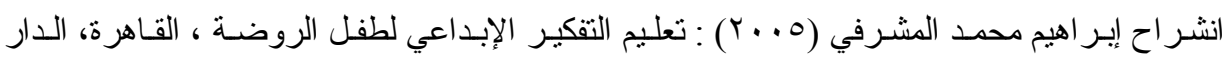
المصرية اللبنانية.

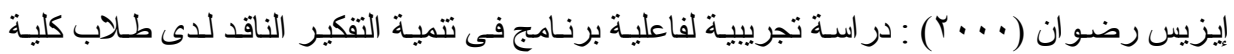

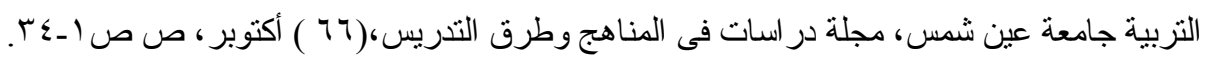

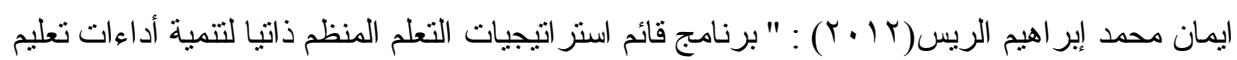

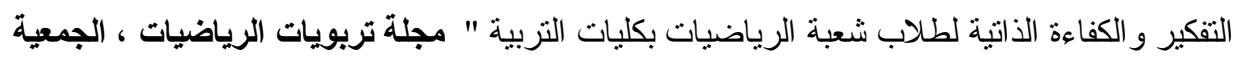

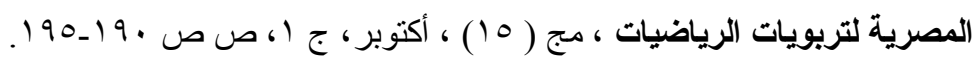

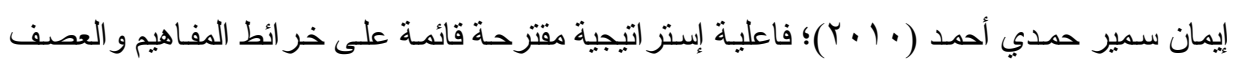

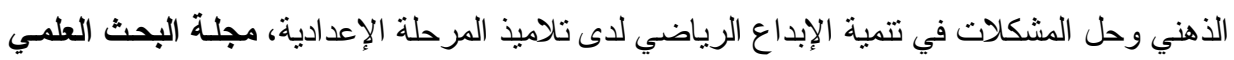

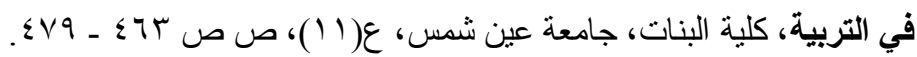

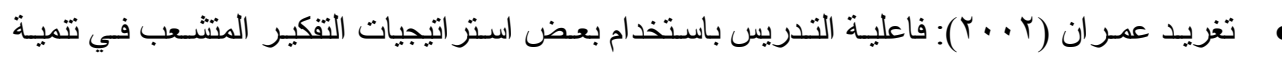

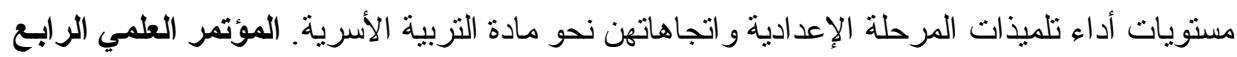

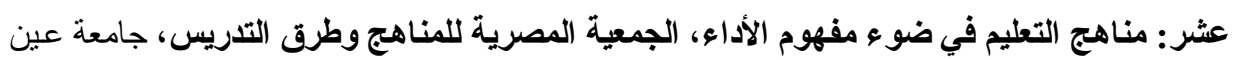

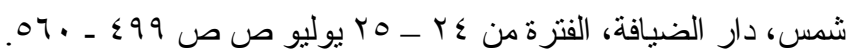




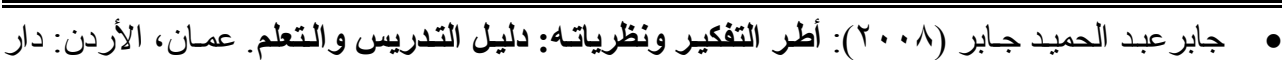

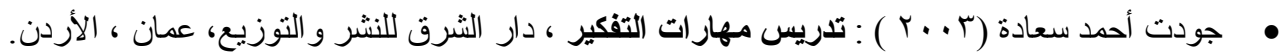

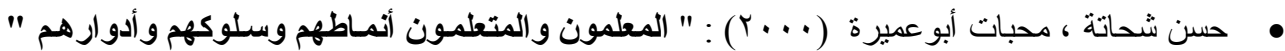
القاهرة ، مكتبة الدار العربية للكتاب.

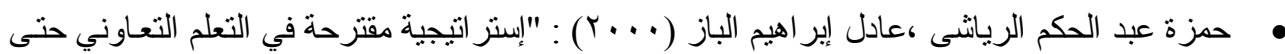

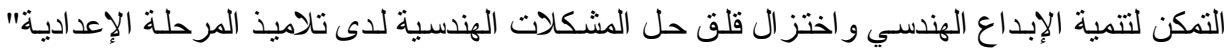

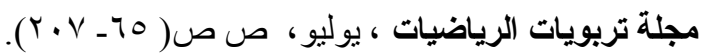

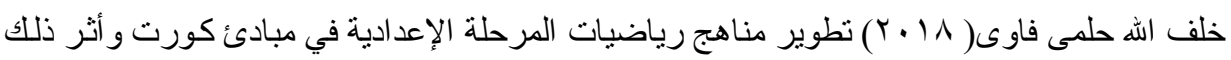

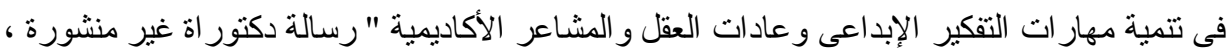
كلية التربية جامعة بنها. خليل ميخائيل معوض (1990 (190) : قرات وسمات الموهوبين " دراسة ميدانية " ، طب، الإسكندرية ، دار الفكر الجامعي.

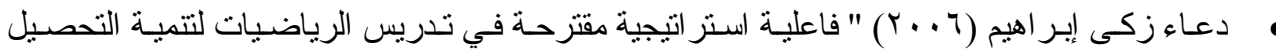

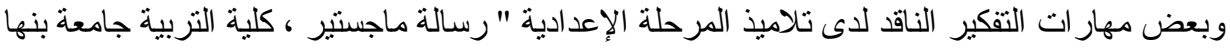

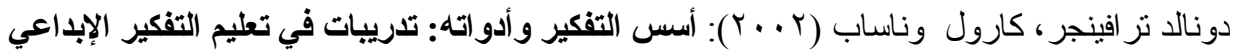
و الناقد.ترجمة منير الحور اني، العين: دار الكتاب الكتاب الجامعي.

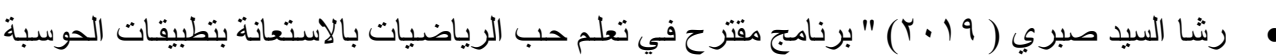
السحابية وقياس أثره على تتمية مهار ات التدريس الإبداعى و الاتجاه نحو التعلم و التعليم عبر الانترنت

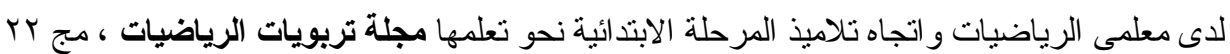

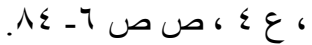

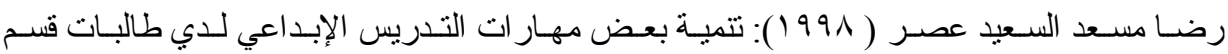

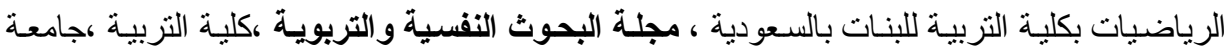

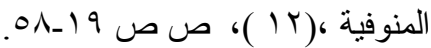

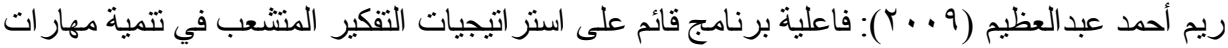

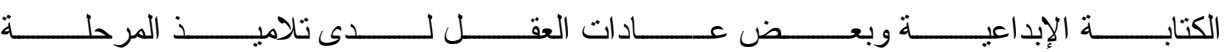

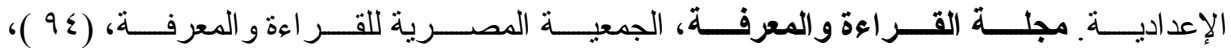

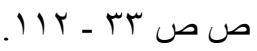




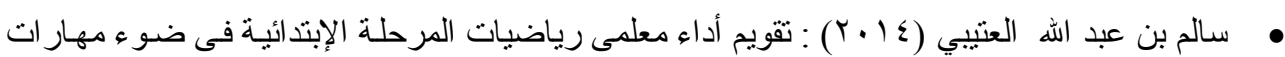
التدريس الإبداعى ، رسالة ماجستير ، كلية التربية : جامعة الطائف بالسعودية .

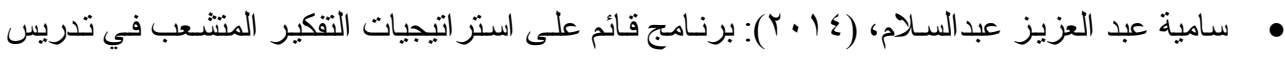
الرياضيات لتتمية القوة الرياضياتية وبعض عادات العات العقل لدى تلاميذ المرحلة الإعدادية. رسالة دكتور اةت، كلية التزبية، جامعة الزقازيق.

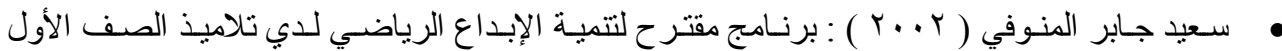

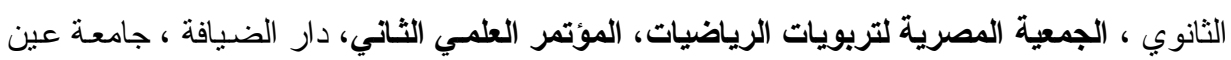
شمس. ملوي بنت سالم برزنجي (10 ب م ) : أثر أسلوب حل المشكلات في تتمية التفكير الإبداعي و القدرة العقلية العليا في مقر الرياضيات لاي طالبات الصف الثاني المتوسط بالمدينة المنورة ، مجلـة تربويات

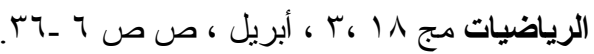

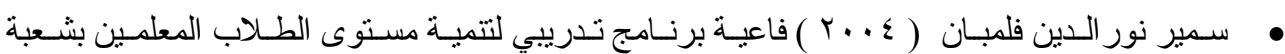

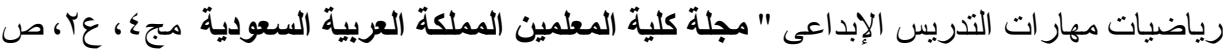

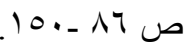

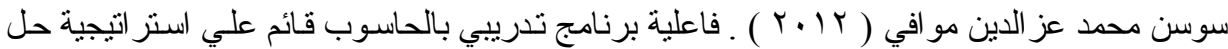

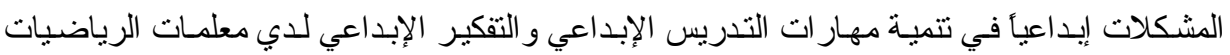
بالمرحلة المنوسطة بجدة ، مجلة جامعة الإمام محمد بن سعود الإسلامية ، العلوم الإنسانية و الاجتماعية

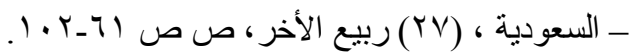

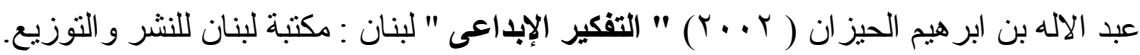

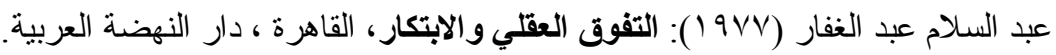

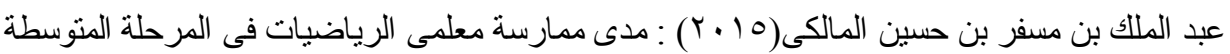

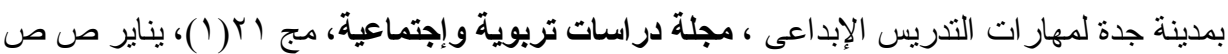
. M - IVr

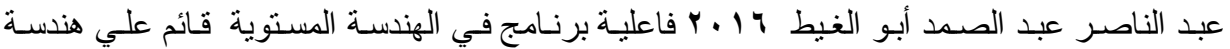

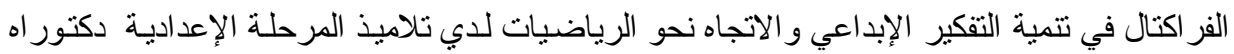
كلية النزبية، جامعة بنها.

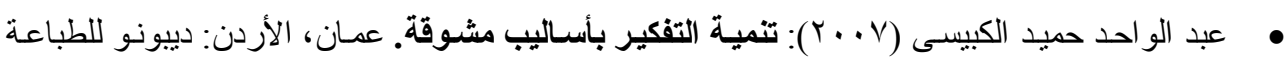
و النشر. 


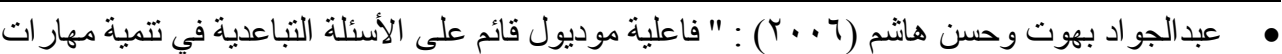

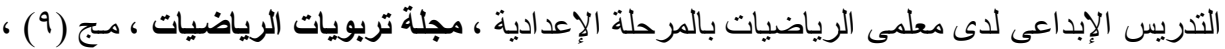

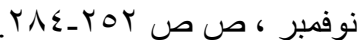

عدنان العتوم و عبد الناصر الجر اح وموفق بثـارة (11 + ب): تنميـة مهارات التفكير : نمـاذج نظريـة وتطبيقات عملية. عمان، الأردن: دار المسيرة.

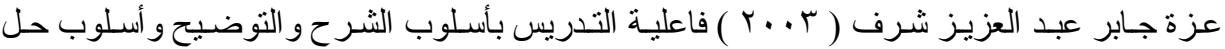

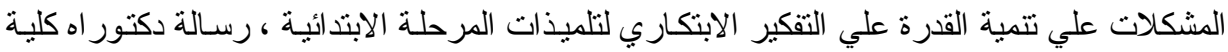
التربية الرياضية للبنات ،جامعة حلو ان. • عـزيزة السيــ (1990) : التفكير الناقد، دراسـة في علم النفس المعرفى، الإسكندرية: دار المعرفة

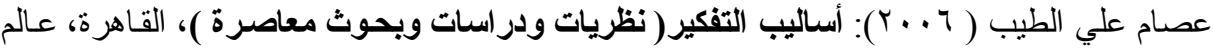
الكتب

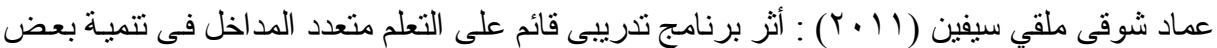

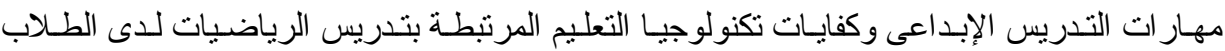

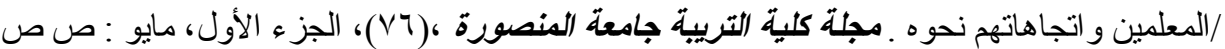
$\varepsilon O V_{-} \varepsilon r Y$

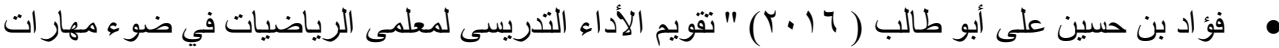

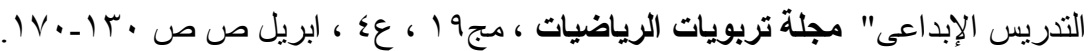

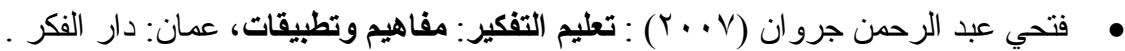

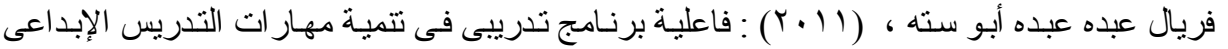

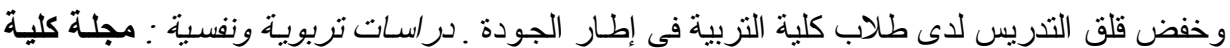

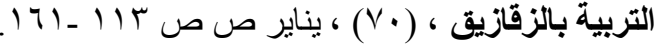

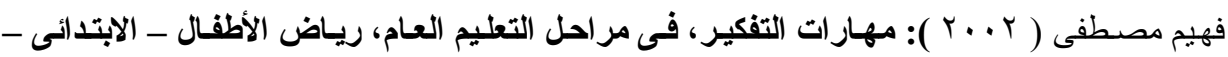

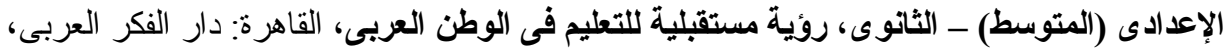

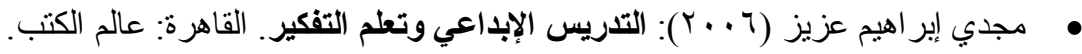

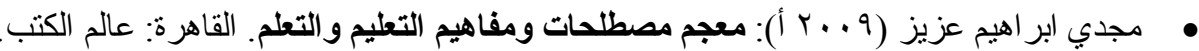

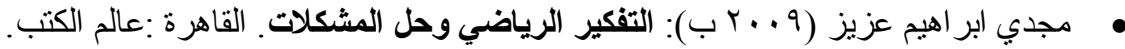

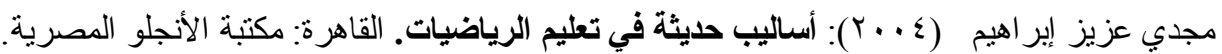




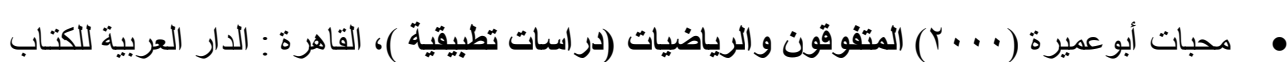

r. ra

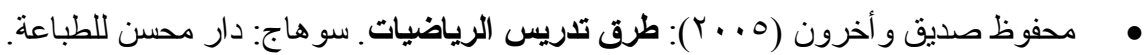

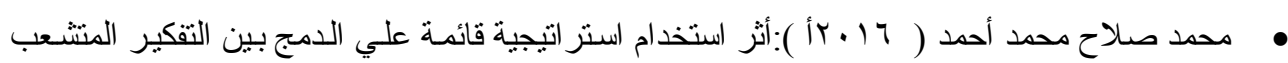

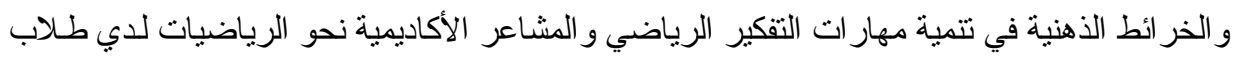
المرحلة الثانوية ، رسالة دكتور اه ، كلية التزبية ، جامعة بنها.

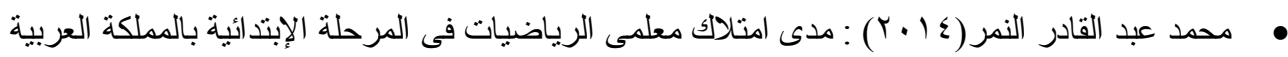

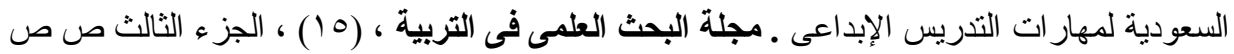

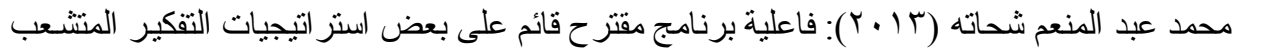

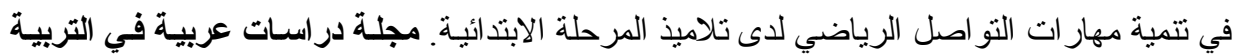

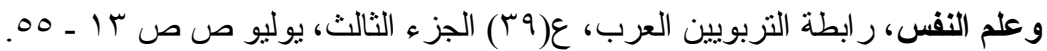

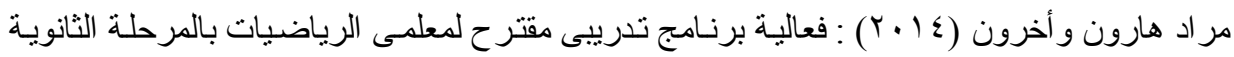

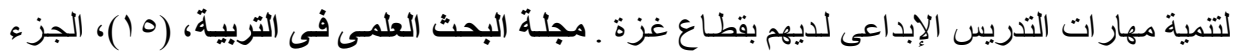

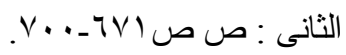

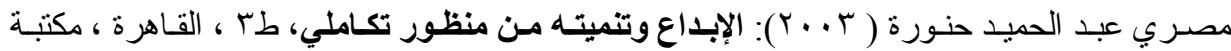
الأنجلو المصرية.

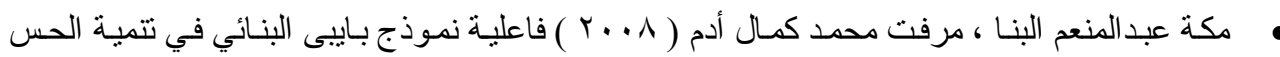

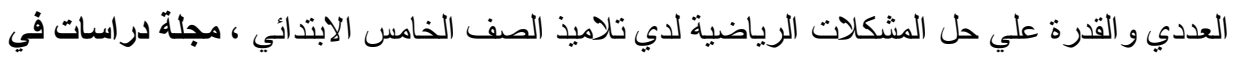

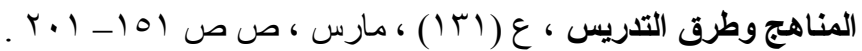

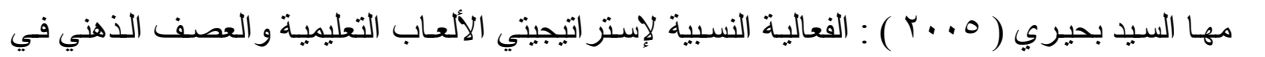
تدريس الرياضيات علي تتميـة الإبداع الرياضي و التحصيل لدي تلاميذ المرحلة الابتدائية ، رسـالة ماجستير ، كلية التربية ،جامعة الزقازيق.

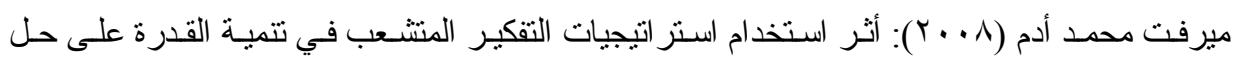

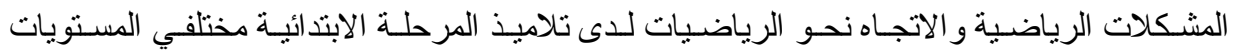

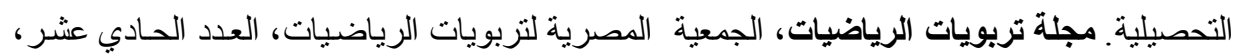




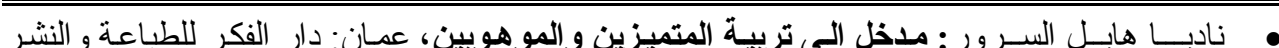
و التوزيع، 1991.

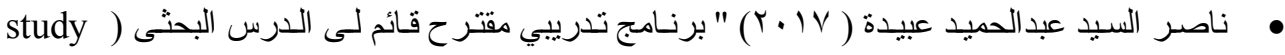

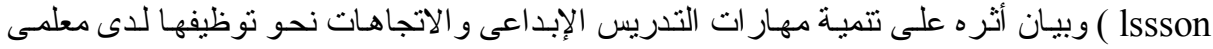

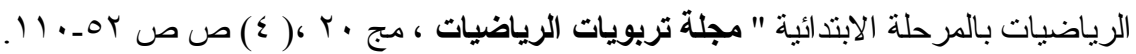

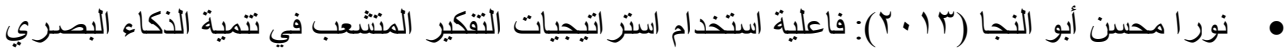

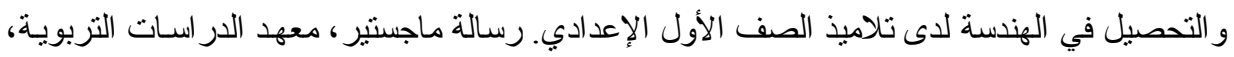
جامعة القاهرة.

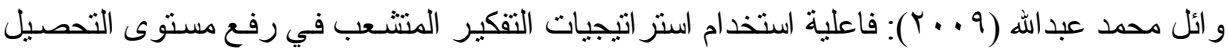

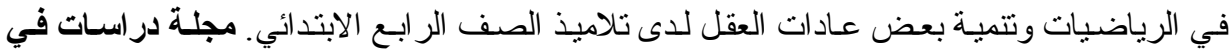

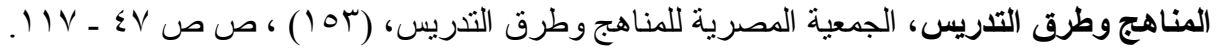

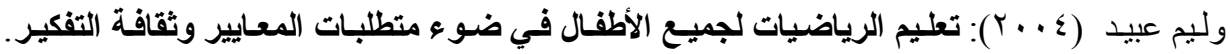
عمان، الأردن: دار المسيرة وليم عبيد (1) (1) استر اتيجيات التعليم و التعلم في سياق ثقافة الجودة ، عمان ، دار المسيرة للنشر و الطباعة . ولئ.

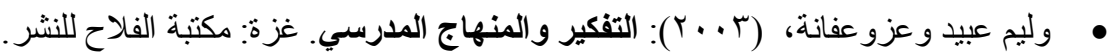

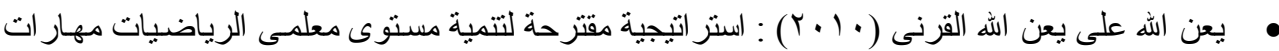

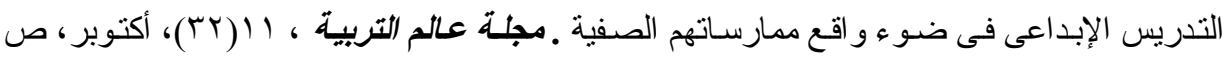

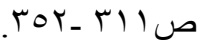

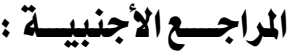

- Cardellichio, T. And Field, W. (1997):" Seven Strategies That Encourage Neural Branching". Educational Leadership ,.45, Issue 6. , 33- 44.

- Dehaan , R. (2009): Teaching Creativity And Inventive Problem Solving in Science. Life Sciences Education, (8), , 172 - 181.

- Dilek, A.(2012). " Imitation or creation : The effects of visual material in basic design Education " Procedia - Social and Behavioral Sciences, (51),368-372.

- Epstein, R. (2006): Critical Thinking.mes Wadsworth: Australia. 
- Hosseini,A . (2016)," Survey The Infliuence of the Creativity Teaching Model On Teaching Skills. Inter national Journal of Sociology Of Education , 3 ,(2), 106-117.

- Jeffrey ,B.,\&Troman,G. (2013) " Managing creative teaching and performative practices " Thinking Skills and Creativity, 9, 24-34.

- Jevffery,B.,\&Craft, A. (2004). " Teaching Creatively and teaching for Creativty : distinctions and relationships " . Educational studies 30 (1),77-87.

- Karim Sevari and Maryam Falahi (2018) : The Effectiveness of Math Educational Software on Creativity and Academic Achievement, Psychology and Behavioral Science International Journal, 8, Feb. ,1-8

- Kwon , O. ; Park , J. (2006): Cultivating Divergent Thinking in Mathematics Through an Open-Ended Approach. Asia Pacific Eduction Review. 7 , (1), 51- 61.

- Mar'atun Hasanah \& Edy Surya (2017): Differences in the Abilities of Creative Thinking and Problem Solving of Students in Mathematics by Using Cooperative Learning and Learning of Problem Solving, International Journal of Sciences: Basic and Applied Research (IJSBAR) 34, (1) 286-299.

- Mason, M. (2008): Ctitical Thinking And Learning. Black Well Publishing :Victoria.

- Mollie,A.(2008) "Analysis of Creative and Effective teaching behaviors of university instructors" Doctor of philosophy of education ,Faculty of the Graduate School ,University of Missouri,State: United States.

- Pound ,L.,\&Lee,T.(2011) Teaching Mathematics Creatively .Routledg Taylor \& Francis Group ,Madison A venue, New York : U.S.A.

- R H Kuncorowati, Mardiyana and D R S Saputro (2017) : Mathematics creative thinking levels based on interpersonal intelligence Universitas Sebelas Maret, Jl. Ir. Sutami No.36 A, Surakarta 57126, Indonesia. 
- Sanja , P.,Tatjana , A. , Dean, L. ,\& Marzanna , K . (2014 ) . " Analyses of students achievement depending on mathematics teaching methods ". Procedia - Social and Behavioral Sciences, 116, 4035 - 4039.

- Schacter ,J.,Meng,y.\&Zifkin,D.(2006)."How Much Does Creative Teaching Enhance Elenentrary School Students Achievment ?" Journal of Creative Behavior,40(1)46-72 .

- Unal , H And Demir , I (2009): Divergent Thinking And Mathematics Achievement in Turkey: Findings From The Programme For International Student Achivement. Procedia Social And Behavioral Sciences. 2 (8) , 1767 -1770 .

- Wood,R.,\& Asfield,J. (2008) "The use oF the interactive whiteboard for creative teaching and learning in literacy and mathematics: a case study", British journal of Technology, 39 (1) ,84-96. 